Columbia Business School
Center on Japanese Economy and Business

CENTER ON JAPANESE ECONOMY AND BUSINESS

日本经济经営研究所

Working Paper Series

July 2016, No. 354

\title{
Product Dynamics and Aggregate Shocks: Evidence from Japanese Product and Firm Level Data
}

Robert Dekle, Atsushi Kawakami, Nobuhiro Kitoyaki, and Tsutomu Miyagawa 


\title{
Product Dynamics and Aggregate Shocks: \\ Evidence from Japanese Product and Firm Level Data ${ }^{1}$
}

\author{
Robert Dekle \\ University of Southern California \\ Nobuhiro Kiyotaki \\ Princeton University
}

\author{
Atsushi Kawakami \\ Teikyo University \\ Tsutomu Miyagawa \\ Gakushuin University and RIETI
}

\begin{abstract}
Conceptually linking product adding and dropping to business cycles goes back to at least Shumpeter. We examine the effects of shocks to aggregate productivity, foreign demand, government expenditures, and demand for foreign liquidity on the dynamics of products of heterogeneous firms. Our structural empirical specifications connecting macroeconomic shocks to product dynamics are based on a neoclassical dynamic general equilibrium model (Dekle, Kiyotaki, and Jeong, 2014). We first construct unique firm level data on products and exports from the Japanese Census of Manufactures. The data are more disaggregated than comparable U.S. data and available at the annual frequency (while U.S. product level data are only available at five year intervals), which makes our data more suitable for examining the interaction between the business cycle and firm-product dynamics. We find that positive macroeconomic shocks in total factor productivity, government demand, and real exchange rates strongly increase the number of products.
\end{abstract}

This Version: July 2016

\footnotetext{
1 We thank Joel David, Steven Davis, Masahisa Fujita, Masayuki Morikawa and Kyoji Fukao and conference participants at USC and ABFER for helpful comments on an earlier draft. This study is conducted as a part of the Project "Study on Productivity Growth at the Firm Level” undertaken at Research Institute of Economy, Trade and Industry (RIETI), and supported in part by a Grant-in-Aid for Scientific Research from the Ministry of Education, Culture, Sports, Science and Technology (No. 22223004 and No. 15H03351) of Japan and the U.S. National Science Foundation.
} 


\section{Introduction}

The entry and exit of products are one of the main drivers of productivity growth. The entry of new products can lower prices and spur productivity and real GDP growth. Earlier empirical work have shown that product dynamics are a major source of productivity movements over the medium- and long-runs. ${ }^{2}$ There is, however, scant theoretically grounded empirical work on how macroeconomic shocks affect the entry and exit of products at the business cycle frequency. ${ }^{3}$ The main concern of this paper is how business cycle shocks such as total factor productivity, foreign demand, and government demand affect product dynamics at the firm level: the entry and exit of firms, and the adding and dropping of products by incumbent firms.

Figure 1-1 shows the movements of shipments in the manufacturing sector in Japan from 1999 to 2009, which are highly cyclical. The first recession which occurred from 2000 to 2002 was affected by the collapse of the IT bubble economy in the U.S. The second recession starting in 2007 was affected by the global financial crisis. We see that during both recessions, the growth in manufacturing shipments was negative (solid line). The movements in shipments can be decomposed into the following components: new firm entry, firm exit, product adding of incumbent firms, product dropping of incumbent firms, and changes in continuing products by incumbent firms. An exiting firm is defined as a firm that drops from one or more products to zero products.

Focusing on just the two recessionary periods, we find that the movements in the components are much larger than the decline in total shipments. The decline in total shipments was driven by large decreases in continuing products of incumbents, the net dropping of products by incumbents,

\footnotetext{
2 See for example, Aghion et. al. (1992), and Bernard, Redding, and Schott (2010).

3 There are several studies that relate firm entry and exit to aggregate shocks. See Alessandria and Choi, 2007; Ghironi and Melitz, 2005; Corsetti, Martin, and Pesenti, 2007; and Moreira, 2016 among others.
} 
and the net exit of firms (exit minus entry).

From Figure 1-1, we can see that the contribution of product adding or dropping (or the sum of the contributions of firm entry and exit and the dropping and adding of products by incumbent firms) is much larger than the contribution of simply the entry and exit of firms. Thus, it is important to not only to focus on the entry and exit of firms, but to separately examine the adding and dropping of products of incumbent firms.

\section{(Insert Figure 1-1 here)}

The key takeaway is that on average between 1999 and 2009 and even just during downturns, firms are entering and adding products at the same time as they are exiting and dropping products. Thus, in analyzing product dynamics at the firm level, we need macroeconomic models that allow for the simultaneous adding and dropping of products of incumbent firms at the business cycle frequency—or of multiproduct firms in dynamic general equilibrium.

In this paper, we empirically relate firm-level product dynamics to macroeconomic shocks such as aggregate productivity, foreign demand, government expenditures and real exchange rates at the business cycle frequency. Our empirical specifications are motivated by the Dekle, Jeong and Kiyotaki (2014) (referred as DJK hereafter) multiproduct firm model. DJK develop a dynamic general equilibrium model in which the products added and dropped at the firm level depends upon aggregate shocks ${ }^{4}$ Firms are heterogeneous, facing recurrent firm-product specific shocks and aggregate shocks, such as shocks to aggregate productivity, foreign demand and liquidity preference. Each firm potentially can produce multiple products and decides whether and how much to produce each product in domestic and export markets. From their model, we can trace how certain macroeconomic shocks can determine product entry and exit, and thus the evolution of the

\footnotetext{
${ }^{4}$ Bilbie, Ghironi and Melitz (2012) also relate product level dynamics to macroeconomic shocks. They do not, however, relate macroeconomic shocks to product adding and dropping at the firm level, since the authors model only single-product firms.
} 
number of products and product adding and dropping rates. The authors show that an aggregate productivity improvement lowers the costs of the entry of new establishments and products and raises the total number of products. Shocks to increase foreign demand and government expenditures also encourage entry and raise the total number of products.

Our aim is estimating the impact of macroeconomic shocks on product entry and exit at the firm level. To the best of our knowledge, this paper is one of the first to estimate a model of product adding or dropping at the firm level at the business cycle frequency, with well identified macroeconomic shocks, such as total factor productivity, foreign demand, and government demand. The estimated equations are "structural" in the sense that the specifications are based on a dynamic general equilibrium model and that the explanatory variables are exogenous or predetermined (if the model is true). We show that aggregate productivity improvements, foreign demand, and government demand expansions all increase the number of products. Positive aggregate productivity and government demand shocks increase the product adding rate.

We obtain our product level data used in this paper from the Japanese Census of Manufactures. The Japanese Census of Manufactures is unique in that the value of shipments can be obtained all the way down to the 6-digit level (which we "products"), and the product level shipment data and establishment (and firm) level accounting data are available at the annual frequency, making the data suitable for analysis at the business cycle frequency. Moreover, to use the framework of DJK, we need to aggregate the product level data up to the firm level. The Census of Manufactures allows this aggregation. Products can be aggregated into establishments (plants), and plants can be matched to the parent firm using firm identifiers. ${ }^{5}$ Aside from testing the mechanisms of product

\footnotetext{
5 In U.S. Census data, the usual product level data are only available down to the 5-digit level and are not available at the annual frequency (Bernard, Redding, and Schott, 2010). Also, although available at a higher frequency, U.S. store scanner-type product level data as used by Broda and Weinstein (2010) and U.S. Bureau of Labor Statistics individual producer price level data used by Nakamura and Steinsson (2012) need to be first matched to firm level accounting data at the annual frequency before performing the
} 
dynamics in macroeconomic models, this paper's regressions themselves are a contribution, since estimates of the impact of macroeconomic shocks on the number of products, and on product adding and dropping behavior are rare.

An important feature of macroeconomic models with product dynamics such as DJK is that much of the macroeconomic adjustment occurs through the extensive margin at the product level, the entry and exit of products. DJK use this feature to explain the puzzle of why exports at the aggregate level are not significantly correlated with the real exchange rate, while exports at the firm level are correlated (a version of the "exchange rate disconnect” puzzle). Their explanation relies on the heterogeneity of the product mixes of firms with large and small export sales. Because products with large export sales tend to have higher productivity (as in Melitz, 2003), a liquidity shock to appreciate their currency will not induce the dropping of such products from the export market and will not greatly lower their total export sales. Since these high productivity products dominate total exports, total exports become insensitive to real exchange rate fluctuations. ${ }^{6}$ On the other hand, products with marginal productivities tend to 'drop like flies' from the export market with adverse shocks and their export sales tend to be sensitive to the exchange rate appreciation. Since products with marginal productivities are more common than products with very high productivity, firm level exports are more sensitive than aggregate exports to shocks which move the exchange rate.

We find using our firm-product level data that firms with high productivity drop products at a

empirical work that we do here.

${ }^{6}$ Berman, Martin, and Meyer (2011) develop a model in which high productivity firms are insensitive to exchange rate fluctuations. In their model, high productivity firms lower price-cost markups, thereby protecting their export market share (quantities). Using Brazilian customs data, Chatterjee, et. al. (2013) also focus on changes in firm-level markups in response to exchange rate fluctuations. In the DJK model, the adjustment in export quantities of high productivity firms are less because high productivity firms drop fewer products when their exchange rate appreciates. 
slower rate than firms with lower productivity when the real exchange rate appreciates. We also find that export sales of more highly productive firms are less sensitive to real exchange rate fluctuations, thus lending support to DJK's explanation of the "exchange rate disconnect puzzle," that changes in aggregate exports are dominated by large firms.

Our paper is organized as follows. In the next Section, we motivate the empirical specifications in this paper. In Section 3, we explain the construction of our product-firm level dataset. We explain how we construct Total Factor Productivity at the firm and industry levels; and foreign demand, government demand and the real effective exchange rates at the industry levels. In Section 4, using our constructed data set, we provide an overview of product dynamics and exports in Japanese manufacturing firms. In Section 5, we present our estimates on the effects of shocks to aggregate productivity, foreign demand, government spending, and real exchange rate on the number of products, product adding and dropping rates, and exports at the firm level.

\section{Product Dynamics and Macroeconomic Shocks}

Dekle, Jeong, and Kiyotaki (2014) construct a dynamic general equilibrium model of a small open economy with a rich production structure. Firms are heterogeneous and potentially produce many differentiated products. Their model differs from the usual general equilibrium, dynamic models of firm entry and exit in that their focus is on the addition and deletion of products by incumbent firms, as well as firm entry and exit. Thus, the authors focus on developing the product evolution mechanism of both entering and incumbent firms.

When a new firm or a new establishment of an incumbent firm pays a sunk cost to enter, it draws an opportunity to produce a new differentiated product with a certain probability of success. The productivity of a new product is heterogeneous and is distributed according to a Pareto distribution with success. The firm with the production opportunity must pay a fixed cost 
in order to produce the product and maintain the productivity. Firms that pay the maintenance cost may succeed or fail to maintain the productivity. In addition, independently from the success or failure of maintaining the existing product, each product that the firm pays the maintenance cost yields an opportunity to produce another new product with certain probability, and the productivities of new products are distributed according to a similar Pareto distribution. ${ }^{7}$ Through these birth and death of differentiated products and entries of new establishments, the firm may add new products, maintain the existing products, replace the products, or drop the existing products. Let $N_{i}(t)$ be the number of products firm $i$ produces and maintains at date t. It evolves according to

$$
\Delta N_{i}(t)=N_{i}(t+1)-N_{i}(t)=\text { entries }+ \text { spinouts }- \text { unsuccessful maintenance }
$$

The first term is the adding of new products due to successful entry of new establishments; the second term captures the new products added by spinning out from existing products, and the last term is the drop of existing products due to unsuccessful maintenance. Here we extend the interpretation of DJK model so that both new and existing firms pay sunk costs to enter to draw new products. The firm is defined as a collection of differentiated products, each having heterogeneous productivity. Note that in the DJK model, even when there are no macroeconomic shocks, firms enter and exit, and add and drop products in the stationary state. This is consistent with Figure 1-1, when there is product churning (simultaneously adding and dropping products) whether there is a boom or a recession.

Firms also face recurrent aggregate shocks, including aggregate productivity, foreign

\footnotetext{
7 The idea here is that new products “spin-out” from old products. Say, Apple is working on the I-pod. Whether the I-pod will continue to be successful or not is stochastic, but only by working on the I-pod will there be a chance that the I-phone will be "spun-out” (they are based on similar technologies).
} 
demand, and liquidity preference shocks. Consumers supply labor, consume final goods (which is produced from many differentiated intermediate products), and hold home and foreign bonds to maximize expected utility. Free entry and aggregate market clearing conditions characterize the competitive equilibrium for the small open economy.

The entry of new firms and new establishments (of incumbent firms) depends on the free entry condition, where the firm or establishment enters when the costs of entry are lower than the expected present discounted value of profits. Macroeconomic shocks affect this firm or establishment entry through the free entry condition. Positive aggregate productivity shocks raise entry by lowering costs. Foreign demand and government expenditure shocks stimulate entry by raising expected revenues.

Suppose that a positive macroeconomic shock hits the firm. The positive shock raises the present discounted value of profits facing the firm, and the firm opens a new establishment to start a new product line. At the same time, through unsuccessful maintenance, the firm loses products. Thus, as observed in Figure 1-1, we can simultaneously see the adding and dropping of products even in response to a positive macroeconomic shock.

The DJK is a neoclassical growth model with a well-defined steady-state. As in such models, the steady-state aggregate number of products, $\mathrm{N}^{*}$, is invariant to aggregate, macroeconomic shocks. When a positive macroeconomic shock hits and raises $\mathrm{N}(\mathrm{t})>\mathrm{N}^{*}$, over time $\mathrm{N}(\mathrm{t})$ decreases from above returning back to steady-state $\mathrm{N}^{*}$. Between the time of the macroeconomic shock and reaching the steady-state, $\mathrm{N}(\mathrm{t})$ is higher than at the steady state. There are more products and the level of GDP is higher after the positive macroeconomic shock than in the steady-state. Owing to the model's product adding and dropping mechanism, adjustment to the steady-state is slow in the DJK. In the calibrated annual version of the model, after a onestandard deviation macroeconomic shock, it takes about 20 years to reach the steady-state. In sum, in the DJK model, positive macroeconomic shocks raise the number of products above the 
steady-state for a long time.

Equation (1) above can be estimated by firm level data with information on the number of products by firms. Note that $N_{i}(t+1)-N_{i}(t)=\Delta N_{i}(t)$ depends on the exogenous stochastic shocks that affect the firm's draws of maintenance and spinouts from the existing products, as well as the endogenous choice of the firm to add new establishments and draw new products. We expect $\Delta N_{i}(t)$ to be a decreasing function of $N_{i}(t)$ as existing firms tend to have a smaller number of spinouts and innovation than the unsuccessful maintenance of existing products. That is, there are negative scale effects in the introduction of new products by incumbent firms. In fact, this negative scale effect—or decreasing returns to scale at the firm level—is a necessary condition for the DJK model to have a steady-state. Only through the entry of new firms and establishments, will the total number of products be maintained or increasing over time.

We also expect the change in the number of products of firm $i, \Delta N_{i}(t)$, to depend on the macroeconomic shocks that impact the entry of new firms and establishments (of incumbent firms) at time t. In our regressions, we include macroeconomic variables such as industry level aggregate TFP, foreign demand, and government expenditures that affect the path of $\Delta N_{i}(t)$ through the free entry condition. In DJK, these macroeconomic shocks are exogenous by construction. We also include the ratio of firm level TFP to aggregate TFP in the regressions. Firm level TFP depends on the history of productivity draws of the products of firm $i$ and is predetermined. If a particular firm $i$ has high TFP relative to other firms, then the firm is more likely to maintain the existing products to induce the spinouts and give birth to new establishments that can satisfy the free entry condition.

We estimate (1) using Japanese firm level panel and industry level data. The number of products, $N_{i}(t)$ is available from the Census data, and the TFP by firm can be calculated using firm level balance sheets. Since firms enter and exit continuously, the panel data is unbalanced.

Macroeconomic shocks such as TFP, foreign demand and government expenditures are 
calculated at the industry level to increase the cross-section variation and the precision of the estimates. The assumption is that the industry level shocks depend upon aggregate shocks, with the sensitivity of the aggregate shocks differing by industry. ${ }^{8}$ We try two different types of macroeconomic (industry level) shocks. First, we include the levels of the macroeconomic variables as themselves. Second, we include only the "surprise" component of the macroeconomic variable. The industry level macroeconomic variables are assumed to evolve as an AR(1) process, and the "surprise" is calculated as the residual component.

\section{The Japanese Census of Manufacturers Data and the Construction of Explanatory Variables.}

We construct our firm-product data using the Census of Manufacturers conducted by the Japanese Ministry of Economy, Trade and Industry. The Census is in principle, a survey of all establishments (plants) in the Japanese economy. The data are now available in the format that we require from 1998-2009 annually. Importantly, unlike in the U.S., where usable product and establishment level data are available for only every 5 years (Bernard, Redding, and Schott, 2010), in Japan, we can collect product and establishment level Census data for every year, which is more conducive to analysis at the business cycle frequency, where peaks to troughs can occur in a period as short as 2 years. We examine versions of the Census that surveys establishments at and above 5 workers, since the data covering establishments below that number of workers are not made publicly available. In 2008 for example, 263,061 establishments of 5 or more employees responded to the Census, representing over 59 percent of all Japanese manufacturing establishments.

\footnotetext{
8di Giovanni, et. al. (2014) use sectoral shocks to measure aggregate shocks, when they examine the effects of aggregate shocks on firm-level sales growth. We use a more precise measure of industry-level shocks.
} 
We define "Sectors" as goods at the 2-digit Japanese Standard Industry Classification (JSIC) level; "Industries" as goods at the 4-digit JSIC level, and "Products" as goods at the 6-digit JSIC level $^{9}$. In the data, each establishment reports the usual accounting data, such as the number of employees, raw material costs, fuel and electricity costs, tangible fixed assets, and the value of shipments (output) of the different types of "products" that the establishment produces.

Given that decisions on adding and dropping products and on output volumes of each product are made at the firm level and not at the establishment level, both in reality and in the DJK (2014) model, we need to identify the "firm". One problem with the Japanese Census data is that the data do not record a firm level identifier that would allow the grouping of establishments into firms (Bernard and Okubo, 2013). Abe et. al. (2012) developed a procedure to match establishments (plants) to their parents by using information on establishment codes, address codes, and industry classifications. Using their procedure, we aggregate establishment level data into firm-level data.

Stylized facts of the Census data concerning multiple product firms are documented in Kawakami and Miyagawa (2010). Briefly, according to Kawakami and Miyagawa, in the Japanese Census, the share of multiple product firms in the total number of firms is about 40 percent, and the average multiple-product firm in Japan produces about 3 products (i.e., three different 6-digit JSIC level products). While multiple product firms represent a minority of firms, they account for 78 percent of total shipments by Japanese firms. The output (shipments) of an average multiple product firm is 50 percent higher than the average single product firm; and average employment is 28 percent higher than a single product firm. Output per worker is 30 percent higher on average in

\footnotetext{
9 Industry classification in the Census of Manufacturers follows the Japan Standard Industry Classification (JSIC) in the case of 2-digit and 4-digit levels. JSIC that started in 1949 is revised every five years. Every version of JSIC is adjusted to adhere to the International Standard Industry Classification (ISIC). However, in the case of the 6-digit classification, the Census of Manufacturers adopts its own classification. An example of sector, industry, and product level classifications are shown in Table 1.
} 
multiple product firms than in single product firms.

In the Census, we also can identify whether a particular establishment is an exporter (export value $>0$ ) and the total value of their exports in that year. However, export values or quantities are only available at the establishment level and not at the product level. At the product level, only total (not broken down into domestic and export) shipment quantities and values are available.

For our empirical analysis, we need to construct some variables using both the Census of Manufacturers and other, mostly industry-level data. We estimate a production function at the firm level by employing the method by Olley and Pakes (1996) to measure Total Factor Productivity. To obtain the necessary accounting data such as the number of employees and value added at the firm level, we simply aggregate the data for all the establishments that the firm manages. Using the estimated coefficients, we measure Total Factor Productivity at the firm and industry levels as described in the Appendix.

We construct industry level foreign demands by first obtaining exports from Japan to 4 of Japan's main export partners (in yen), the U.S., China, the European Union, and Russia in each industry (these countries account for over 90 percent of Japan's total exports). We then obtain the value added in each of Japan's export partners in each industry from the IMF's International Financial Statistics (converted to yen at the prevailing exchange rate). For each industry, we then sum Japan's exports and value added over the 4 countries. Finally, for each industry, we take the ratio of Japan's summed exports to our summed value added measure, and use this ratio as our foreign demand variable. The data on industry level government expenditures are obtained from the Input- Output Tables in Japan Industrial Productivity Database (JIP database). ${ }^{10}$

10 Hitotsubashi University and Research Institute of Economy, Trade, and Industry have constructed this database to estimate productivity at the industry level. The concept of this database is consistent with other productivity database such as Jorgenson, Gollop, and Fraumeni (1987) and EUKLEMS database. The JIP database is published at the website; http://www.rieti.go.jp/en/database/JIP2014/index.html\#04-1. 
We obtain the industry-level real effective exchange rate data from the Research Institute of Trade, Industry, and Economy (RIETI) from 2005 to 2009. As the period of our firm-product database is from 1999 to 2009, we have to construct real effective exchange rate data from 1999 to 2004. As for this data from 1999 to 2004, we choose China, EU, Russia, and the US as trade partners. We obtain trade data from the Trade Statistics published from the Ministry of Finance in Japan. The industry-level output price data are obtained from the World KLEMS database (http://www.worldklems.net/). We use nominal exchange rates from the IMF's International Financial Statistics. Our estimates of real effective exchange rates thus constructed runs from 1999 to 2007. We link our data to the RIETI data in 2005.

In DJK, actual real exchange rate movements are dominated by aggregate liquidity shocks, so they include exogenous aggregate liquidity shocks in their model. However, it is difficult to find variables that capture aggregate exogenous liquidity shocks in the data. Also, there is a tradition in international finance starting from Meese and Rogoff (1981) that include exchange rates as exogenous variables in estimations. Meese and Rogoff justify this practice by pointing out that exchange rates are a random walk process and fundamental variables such as productivity and monetary shocks have little explanatory power in predicting exchange rates. Below we include the industry-level real effective exchange rate and its cross term with relative TFP as an explanatory variable, being fully aware that this variable could be endogenous. ${ }^{11}$

As a robustness check, instead of the levels of the industry variables, we also measure shocks or "surprises” to the industry-level variables and include these "surprises” as explanatory variables. We assume that the levels of each of the macroeconomic variables are following an AR(1) process (consistent with the impulse response analysis of DJK), and take the residuals as the "surprise" to this macroeconomic process. Thus, for each of our industry-level variables (TFP, foreign demand, and government demand), we estimate an $\operatorname{AR}(1)$ process and use the residuals as additional

\footnotetext{
11 Foster, Haltiwanger, and Syverson (2008) and Syverson (2011) found persistent productivity differences across a cross-section of U.S. firms. The same productivity differences are also found by Fukao and Kwon (2006) and Kawakami, Miyagawa, and Takizawa (2012).
} 
explanatory variables that measure "surprises" to the macroeconomic variables.

\section{Stylized facts of Product Dynamics.}

Using the firm-product level data as constructed above, here we provide an overview of product level dynamics in Japan. Table 1 shows examples of sectors, industries, and products in Japan. Table 2 depicts how sectors can be divided into industries and products. For example, the food sector has 41 industries and 87 products, ships 24 billion yen worth of goods and has over a million workers. We find that the value of shipments (output) per employee is higher in industries with high capital intensity, such as the coal and the petroleum sector.

(Insert Tables 1 and 2 here)

As shown in Introduction, Figure 1-1 depicts the decomposition over time of the total change in shipments (output, solid line). Over the entire period, the biggest contributor to total shipment movements is the fluctuation in continuing products made by incumbent firms. Some continuing products expand their shipments while others contract, and their difference is pro-cyclical.

(Insert Figure 1-1 here)

The second important contributor to the movement in total shipments is the adding and dropping of products by incumbent firms. Compared to the contribution of products added and dropped, the contribution of the entry and exit of firms to total shipment fluctuations is rather small. With respect to the introduction of new products, the shipment of new products by incumbent firms dominates the shipment of new products by new firm entrants. In addition, during booms, product adding dominates product dropping, suggesting that positive macroeconomic shocks stimulate net 
product adding and increase the number of products.

These stylized facts argue for models that allow for the adding of dropping of products of incumbent firms—or of multiproduct firms. In terms of the multiproduct DJK model, this would mean that the entry of new establishments by existing firms and the spinouts from the existing products dominate the entry of new firms in the movement of total shipments.

Figure 1-2 depicts the decomposition over time in the change in the total number of products. The evolution in the total number of products can be decomposed into the addition of new products by incumbent firms, the addition of new products by the entry of new firms (going from 0 to 1 or more products), the dropping of existing products by incumbent firms, and the exit of incumbent firms (when they drop their last product.) Regardless of whether the economy is in a boom or a recession, there are simultaneously a large number of products added and dropped by existing firms. Compared to the adding and dropping of products by incumbent firms, the contribution to the total number of products by the entry of new firms and exits by existing firms are pro-cyclical. Incumbent firms added products especially strongly between 2003 and 2006. In contrast to the procyclical nature of product adding and firm entry, product dropping and firm entry behaviors are relatively noncyclical. This asymmetry in response to macroeconomic shocks in product adding and in dropping is a feature of our data and is also present in our estimates below. ${ }^{12}$

(Insert Figure 1-2 here)

In Figures 2-1 to 2-4, we divide firms into high productivity and low productivity firms, and examine the changes in shipments and in the number of products. High productivity firms are defined as firms that are in the top $25^{\text {th }}$ percentile of all firms between 1999 and 2009. Low productivity firms are defined as those in the bottom $75^{\text {th }}$ percentile. Since high productivity firms

12 Bernard and Okubo (2015) also document the asymmetric behavior of product adding and dropping over the Japanese business cycle. 
are on average larger, and produce a greater number of products, Figures 2-1 to 2-4 can also be interpreted as splitting firms by scale.

On average, between 1999 and 2009, more productive and larger firms added fewer new products, which is consistent with the presence of negative scale effects. Shipments by highly productive firms are less volatile than shipments by firms of lower productivity. While fluctuations in continuing products are about the same between high and low productivity firms, low productivity firms add and drop products at a higher rate in response to economic fluctuations (Figures 2-3 and 2-4).

(Insert Figures 2-1 to 2-4 here)

In Figure 3, we compare the number of products between exporters and non-exporters. The figures show that the average number of products per exporter is larger than that of all firms. Exporters produce a greater number of products than the average Japanese firm. The Figure also depicts average export values by firm. Compared to purely domestic firms, Japanese exporters are more likely to be multiproduct firms. The fluctuations in total shipments are also larger for exporters than the total shipments shown in Figure 2. Figure 4 shows the distributions of total sales of exporters and non-exporters. The sales of exporters are larger than those of non-exporters (as implied in the models of Melitz 2003 and DJK).

The larger fluctuations in total shipments by exporters are not only because exporters have larger fluctuations in existing products. It is also because exporters add and drop products more rapidly than non-exporters. In Figure 5, the average number of added products equals to 2 for exporters and 1.4 for non-exporters. The average number of dropped products is 1.9 for exporters and 1.3 for non-exporters. Moreover, the average numbers of added and dropped products fluctuate somewhat more for exporters, while the average numbers of added and dropped 
products are very stable for non-exporters. These facts highlight the importance of the export margin in the aggregate adjustment of product shipments and in product adding.

(Insert Figures 3, 4, and 5 here)

Finally, we examine the relationship between extensive margins and exports. In Figure 6, the share of firms adding products and share of entrants (both weighted by shipments) are positively correlated with movements in average export values by firm. Both shares increased when export growth accelerated in the period from 2002 to 2004, and decreased after 2009, when total Japanese exports collapsed, owing the global financial crisis. In Figure 7, the share of firms dropping products and the share of exiting firms are only mildly negatively correlated with movements in exports. Dropping rates are rather insensitive to the business cycle. Again, we observe the asymmetry in product adding and dropping behavior over the business cycle.

To sum up, these stylized facts show that a significant adjustment in Japanese output is comprised of the adding of new products, (in addition to the expansion and contraction of the shipments of existing products). This adding of new products appears more pronounced for Japanese exporters. New product additions by incumbents and new firm entry are also highly procyclical, while the dropping of products and firm exits are not very cyclical. Although not observed at the business cycle frequency, these features are also present in U.S. data (Bernard, Redding, and Schott, 2010). Firms add and drop products at all states of the business cycle. During recessions, both adding and dropping rates increase.

In addition, although we do not observe exports at the product level, we find that exporters tend to be multiproduct firms and that exporters add and drop products at a much more rapid rate than non-exporters. Finally, product adding rates are highly correlated with average firm exports. Thus, while the total cyclical change in shipments is dominated by the change in continuing 
products made by incumbent firms, the cyclical change in export sales is highly correlated with the adding of new products, either by incumbents or by new firms.

(Insert Figures 6 and 7 here)

\section{Estimation of Product Dynamics}

In product level general equilibrium models such as DJK, common macroeconomic shocks such as aggregate productivity, government expenditure, and foreign demand shocks alter product dynamics and export behavior. To analyze their model, DJK shock their model with an AR(1) process of an aggregate shock such as TFP. In their impulse responses, DJK show that a one standard deviation (0.9 percent) increase in aggregate TFP (with auto-correlation of 0.55 in annual data) raises output by 1 percent, and depreciates the real exchange rate by 0.9 percent. Exports increase by 0.7 percent, and correspondingly, the total number of products increases vigorously in 3 to 7 years to 0.4 percent. A 1.4 percent increase in foreign demand (with autocorrelation of 0.94 ) increases GDP by 0.2 percent and exports by 0.8 percent. The real exchange rate appreciates by 0.8 percent, the number of products increases slowly by 0.15 percent in 7 to 20 years. A 0.8 percent positive government expenditures shock (with auto-correlation of 0.95) raises GDP by 0.15 percent, depreciates the real exchange rate by 0.1 percent, and increases exports by 0.07 percent and the number of products by 0.08 percent. Thus, quantitatively, DJK find that aggregate TFP shocks have the greatest impact on the number of products, followed by foreign demand and government spending shocks. Our estimates below are broadly consistent with these quantitative predictions.

In our estimates below, we focus on the extensive margin of adjustment, of the total number of products, and whether the firm adds a product or drops a product, or adds and drops a product at the same time (product churning). The estimated equations are "structural" in the sense that if the DJK model is correct, then the explanatory variables are predetermined (the firm-level 
variables) or exogenous (the macroeconomic shocks). As in typical impulse responses from quantitative models, the coefficients on the macroeconomic shocks estimated below using product-firm level data should be interpreted as the impact effect of the shock or impulse (which dissipate over time) on the dependent variable in question.

\section{Empirical Specifications}

Our empirical specifications are as below:

$$
\begin{aligned}
& \Delta N_{i}=a_{1} * T F P_{i} / T F P_{A}+a_{2} * T F P_{A}+a_{3} * F D_{j}+a_{4} * G_{j} \\
& +a_{5} * R E E R_{j}+a_{6} * \operatorname{TFP}_{i} / \text { TFP }_{A} * \operatorname{REER}_{j}+a_{7} * N_{i} \\
& \triangle P D_{i}=b_{1} * T F P_{i} / T_{F P}+b_{2} * T F P_{A}+b_{3} * F D_{j}+b_{4} * G_{j} \\
& +b_{5} * R E E R_{j}+b_{6} * T_{F P} / \text { TFP }_{A} * R_{E E R}+b_{7} * N_{i}
\end{aligned}
$$

Since firms enter and exit each year, the panel data are unbalanced. In all Tables below, the number of observations refer to the sum of the number of firms in the entire sample $\sum_{t}$ number of firms in year $t$, where entry and exit causes the number of firms to be different in each year. In addition to estimates based on a sample of all firms, we conduct each estimation on a sample of only exporters, where a firm is an exporter when exports $>0$ in year t. ${ }^{13}$ The sample of exporters is also unbalanced, as firms enter and exit the export market. As shown in the Figures 3 to 6 above, compared to a sample of all firms, exporters are particularly active in product adding and dropping.

13 Of course export status is endogenous and depends on the same explanatory variables as in Equation (1) and (2). Panel logit estimates on whether a firm is an exporter are available upon request. 


\section{Dependent Variables}

The dependent variable in Equation (1) is the change in number of products of firm i, $\Delta N_{i}$. Following Davis, Haltiwanger, and Schuh (1996), we also conduct an alternative estimation where the dependent variable is the rate of change in the number of products: $(N(t)-N(t-1)) /(N(t)+N(t-1)) / 2$.

In Equation (2), $P D_{i}$ represents three dependent variables that are intended to capture product level dynamics. They are the product adding dummy (takes a value of unity when the firm adds a product); the product dropping dummy (value of unity when the firm drops a product); and the product adding and dropping dummy (the firm simultaneously adds and drops a product).

\section{Explanatory Variables}

Explanatory variables are the same in all equations. $N_{i}$ is the number of products of firm i, which is predetermined in DJK at time t. $\mathrm{TFP}_{i} / \mathrm{TFP}_{\mathrm{A}}$ is the ratio of TFP in firm $\mathrm{i}$ to industry level aggregate TFP. $N_{i}$ and firm level TFP are pre-determined by the history of new products that the firm has produced up to time t. Given that aggregate TFP is by assumption exogenous, the ratio of firm level TFP to aggregate TFP is predetermined. $F D_{j}$ indicates foreign demand in industry j. $G_{j}$ represents government demand in industry j. $R E E R_{j}$ denotes the industry-level real effective exchange rate.

As mentioned, we use two measures of macroeconomic shocks, the level of the macroeconomic variable, and the "surprise" component of the AR(1) process of the macroeconomic variable. In typical impulse response analysis, the impulses are supposed to be "surprises.” However, in actual time series, it is difficult to separate the expected from the "surprise" component, so for robustness, we use both the level of the macroeconomic variable and its "surprise" component. 


\section{Hypothesized Signs}

An increase in firm level TFP to industry level TFP means that compared to the average firm in industry j, the firm possesses a higher mean level of productivity. This firm will then have a greater incentive to maintain its existing products and add new establishments, which leads to a larger likelihood of adding of products by spinouts and the entry of new establishments. Thus, $a_{1}$ should be positive and $b_{1}$ should be positive in the product adding case. In the product dropping case, $b_{1}$ should be insignificant.

$\mathrm{TFP}_{j}$ represents industry level productivity. Shocks to $T F P_{j}$ are akin to aggregate TFP shocks if industry shocks are proportional to aggregate shocks. The aggregate TFP shock increases the number of products because production costs for new entrants will decline, and more new entrants will be able to meet the free entry condition. Thus, in Equation (1), $a_{2}$ should be positive. In the case of Equation (3), a positive aggregate TFP shock stimulates product adding, making $b_{2}$ positive. The product dropping rate does not depend much on positive aggregate shocks in the DJK model, making the sign of $b_{2}$ ambiguous or insignificant.

The positive foreign demand shock increases the number of products. We expect $a_{3}$ to be positive. In the DJK model, foreign demand stimulates product adding through an increase in revenues, leading to greater establishment and firm entry. Then, $b_{3}$ will be positive when the adding dummy is the dependent variable. The coefficient on the dropping dummy is insignificant, as the firm is dropping products, regardless of whether there is a boom or bust.

An increase in government demand should increase number of products. Thus, $a_{4}$ is expected to be positive. In Equation (2), $b_{4}$ is expected to be positive when the adding dummy is the dependent variable. When the dropping dummy is the dependent variable, $b_{4}$ is again expected to be insignificant.

In the DJK model, movements in the real effective exchange rate depend on aggregate 
productivity, foreign demand, government spending, and liquidity shocks. Thus, the real effective exchange rate is endogenous. However, given the tradition in international finance of assuming the exogeneity of exchange rates, here we assume that fluctuations in real exchange rates are exogenous. An exogenous depreciation in the real exchange rate is akin to an increase in demand for home products. The expected sign for $a_{5}$ is positive. The expected sign of $b_{5}$ is positive when the adding of products is the dependent variable. Again when the dropping of products is the dependent variable, the expected sign of $b_{5}$ is insignificant.

DJK show that firms with high productivity are relatively immune to shocks that cause real exchange rate fluctuations. Thus, compared to the low productivity firms, for highly productive firms, the increase in product adding driven by the depreciation of real effective exchange rate should be smaller; $a_{6}$ should have a negative sign. If the adding dummy is the dependent variable, $b_{6}$ is likely to be negative. Again $b_{6}$ is likely to be ambiguous when the dependent variable is the dropping dummy variable.

\section{Estimation Results}

In Table 3-1, we regress the change in the number of products on the macroeconomic variables. Earlier specification tests indicated that we use fixed-effect panel data with an AR(1) correction of the error term as the preferred estimation method. When the levels of the macroeconomic variables are used, TFP, Foreign Demand, and Government Demand spikes all raise the number of products. When the "surprise” component of the macroeconomic variables are used (columns 3 and 4), the results are mixed, with TFP having a positive effect only for the exporting firms.

A real exchange rate depreciation sharply raises the number of products in all specifications. In all specifications, the number of products of more productive firms are less responsive to an exchange rate appreciation. Firm-level variables have the expected signs. An increase in firmlevel TFP raises the number of products; there are also large decreasing scale effects at the firm 
level (coefficient on $\mathrm{N}(\mathrm{t})$ is negative). Export firms are much more responsive to exchange rate fluctuations in changing the number of their products (as shown in Figure 5). Foreign demand shocks are also more powerful for exporting firms.

In Table 3-2, as the dependent variable, we use the rate of change in the number of products as the dependent variable, $(N(t)-N(t-1)) /(N(t)+N(t-1)) / 2$. The results are robust and identical to those of Table 3-1. All macroeconomic and firm level variables have the expected signs and are significant.

(Insert Tables 3-1 and 3-2 here)

The product adding dummy variable, the dependent variable in Table 3-1, is an integer. As a robustness check, we estimated the specification in Table 3-1 using count data methods (the negative binomial estimator) that are appropriate for discrete dependent variables. The results are similar to those in Tables 3-1 and 3-2 and are not depicted here to save space.

In Table 4-1, we use a variable that denotes whether a firm is adding a product at year t. Since the dependent variable is a $(0,1)$ variable, we estimate the equation by the panel logit estimator. Government demand shocks generally stimulate product adding. The effects of the other macroeconomic shocks are mixed. Again, we see the high sensitivity of product adding in response to exchange rates for exporting firms.

In Table 4-2, we use the rate of product adding (number of products added)/total number of products, as the dependent variable. Here the signs change depending on the specifications. For example, including TFP has a negative sign, when our sample includes all firms, but has a positive sign, when the sample includes only export firms. Consistently significant is the finding that highly productive firms are least influenced by real exchange rate shocks, and that the larger the firm, the lower the product adding rate (negative scale effects).

(Insert Tables 4-1 and 4-2 here)

In Tables 5-1 and 5-2, we use a variable that denotes whether the firm is dropping a product 
at year $\mathrm{t}$ (again by the panel logit estimator). Positive macroeconomic shocks generally increase the dropping of products. In fact, the effect of positive shocks on the dropping of products is larger than on the adding of products. While the DJK model can explain simultaneously, the adding and dropping of products, the reality here seems more complicated than simply the product evolution mechanism modelled by DJK. Especially puzzling is that exporters are dropping products in response to exchange rate depreciations. There appears to be an additional Lucas-type managerial “span-of-control” cost structure at work here. Given the limitations of managerial control, firms which add new and better products tend to drop older products, which makes the adding and dropping of products move sharply in the same direction.

\section{(Insert Tables 5-1 and 5-2 here)}

Finally, in Table 6, as the dependent variable, we use the dummy variable when the firm is adding or dropping a product. The variable takes on a value of unity when the firm is simultaneously adding and dropping a product (product churning). We find in Table 6 that in response to foreign and government demand shocks, the firm is indeed product churning. The firm is not able to add new products, without dropping old products. These results again suggest the presence of a Lucastype managerial "span-of-control” cost structure.

(Insert Table 6 here)

\section{Concluding remarks}

Policy makers in many countries are especially concerned about the new products produced within their borders. For example, the Abe administration in Japan has undertaken expansionary fiscal and monetary policies, partly in the hope of encouraging the introduction of innovative products. ${ }^{14}$ The recent expansionary monetary policy in Euro area is related in part to the desire to stimulate innovation and introduction of better products (Bergin and Corsetti, 2014).

Conceptually linking business cycles with product adding and dropping behavior at the firm

\footnotetext{
${ }^{14}$ In addition to improving overall productivity, new products increases consumer utility in a "love of variety" model.
} 
level is not new; the idea goes back at least to Schumpeter. To the best of our knowledge, this paper is one of the first to estimate a model (DJK, 2014) of product adding and dropping behavior for the multiproduct firm at the business cycle frequency. To estimate such a model, we need product level data that can be matched with firms at a minimum at the business cycle or annual frequency.

We construct a unique firm-product database in Japan using the Census of Manufacturers by the Ministry of Economy, Trade, and Industry. The products in our database are classified down to six-digits, which is more detailed than what is available in the U.S. Census of Manufactures.

In Japan, firms change their product compositions quite frequently, although the average number of products per firm is very stable. This stability, however, hides some significant product adding and dropping behavior. The average number of products of exporters is larger and more volatile than non-exporting firms. Sales of exporters are larger than the sales of non-exporters. We also find that product adding and firm entry behavior are cyclical, while product dropping and firm exit behavior are less cyclical.

In our firm level estimates, we find that macroeconomic shocks-- industry level productivity and government demand shocks — increase both the number of products and product adding and dropping behavior. This producer level behavior is consistent with the DJK model.

Our empirical results suggest that creative destruction of adding new products and dropping old products by incumbent firms is an important contributor to aggregate fluctuations, and more important than the entry and exit of firms for business cycle fluctuations. This creative destruction of products is more active under favorable macroeconomic conditions of high total factor productivity, government and foreign demand, and a depreciated real exchange rate. To revitalize stagnant industrialized countries such as Japan's, it is important for the government to implement policies that raise aggregate productivity, government, and foreign demand, such as improving education, research and development, and stimulating infrastructure and foreign direct investment 
and trade, in addition to reducing the structural obstacles to slow down the product innovation process.

\section{Appendix: Methodology of measuring firm level TFP}

For the measurement of TFP, we employed a production function suggested by Olley and Pakes (1996) ${ }^{15}$. Olley and Pakes (1996) estimated a production function allowing for the endogeneity of inputs, selection bias, and unobserved permanent differences across firms. They specify a production function whose added values $\left(Y_{i t}\right)$ is dependent on capital stock $\left(K_{i t}\right)$, labor input $\left(L_{i t}\right)$, firm age $\left(a_{i t}\right)$ and productivity level $\left(\omega_{i t}\right)$ :

$$
Y_{i t}=F\left(K_{i t}, L_{i t}, a_{i t}, \omega_{i t}\right)
$$

$Y_{i t}$ and $L_{i t}$ are firm $i$ 's value added and labor input at $t$. To calculate TFP using the Census of Manufactures, we assume that the Cobb-Douglas technology function applies:

$$
y_{i t}=\beta_{0}+\beta_{l} l_{i t}+\beta_{k} k_{i t}+\beta_{a} a_{i t}+u_{i t} \text { and } u_{i t}=\omega_{i t}+\eta_{i t}
$$

When $\omega_{i t} \geq \underline{\omega}_{t}$, a firm continues its plant. As this survival rate depends on the past firm age (at-1), capital stock $\left(\mathrm{k}_{\mathrm{t}-1}\right)$, and survival probability $\left(\hat{P}_{i t}\right)$, we rewrite $(\mathrm{A}-1)$ as follows,

$$
y_{i t}-\beta_{l} l_{i t}=\beta_{k} k_{i t}+g\left(\hat{\phi}_{t-1}-\beta_{k} k_{i t-1}-\beta_{a} a_{i t-1}, \hat{P}_{i t}\right)+\xi_{i t}+\eta_{i t}
$$

Equation (A-2) is an unbiased and consistent production function which we estimate. $g(\cdot)$ is approximated by the second-order polynomial in $\hat{\phi}_{t-1}-\beta_{k} k_{i t-1}-\beta_{a} a_{i t-1}$ and $\hat{P}_{i t} \cdot \xi_{i t}$ is TFP for the

15 To estimate the production function suggested by Olley and Pakes (1996), we use the opreg command for STATA. The explanation of estimation in this appendix is following the manual of opreg (Yasar, Raciborski and Poi, 2008). 
survived firms which are not affected by the investment and exit decisions at $t-1$. The definitions of the variables are described below.

\title{
Value added
}

Value added is defined as:

\author{
Value added=total shipment-cost of raw materials \\ -fuels and electricity consumed +value of depreciation
}

Total shipment and materials and fuels and electricity are real values deflated by industry level GDP deflators.

\section{Labor input}

Labor input is defined as man hours, which is the total number of workers multiplied by industry-level working hours.

\section{Capital stock}

For the calculation of the real value of the net capital stock, we multiplied the book value of tangible assets of each firm $i$ at period $t$ by the industry-level market-to-book ratio $I N K_{j t} / I B K_{j t}$ calculated from the Census of Manufactures.

$$
K_{i t}=B V_{i t} * \frac{I N K_{j t}}{I B K_{j t}}
$$

To calculate the market values of tangible asset $I N K_{j t}$ in industry $j$, we take the following steps: 1) for the initial value, take tangible assets in the Census of Manufactures and 2) tangible assets after 1977 are calculated using the perpetual inventory method following the equation below:

$$
I N K_{j t}=I N K_{j t-1} *\left(1-\delta_{j t}\right)+I_{j t}
$$


$I_{j t}$ is the total investment of industry $j$ deflated by JIP2013, $\delta_{t}$ is the depreciation ratio calculated from the Japanese input-output tables..

Because the capital stock is reported by establishments that employ 10 or more employees, we removed firms that employed fewer than fewer than 9 employees from the estimation sample. In the equation to estimate the production function, we added year dummies ${ }^{16}$ as control variables. Table A1 shows the estimated result.

Table A1. Production function by Olley and Pakes (1996)

\begin{tabular}{lccc}
\hline & coefficient & $\mathrm{z}$ & \\
\hline $\operatorname{lnK}$ & 0.124 & 23.04 & $* * *$ \\
$\operatorname{lnL}$ & 0.622 & 129.02 & $* * *$ \\
\hline year dummy & yes & & \\
\hline sample size & 399794 & & \\
number of groups & 70992 & & \\
\hline
\end{tabular}

Note) $* * *$ indicates that the null hypothesis of estimated coefficient is rejected at a significant level $1 \%$.

We measure firm-level TFP by using value added, capital and labor data in the Census by using the coefficients in production factors shown in Table A1. Firm-level TFP is defined as follows,

$\ln T F P_{i}=y_{i}-\hat{\beta}_{l} l_{i}-\hat{\beta}_{k} k_{i}$

We also measure industry-level TFP by using the coefficients in production factors shown in Table A1:

$\ln T F P_{j}=\sum_{i \in j} y_{i}-\hat{\beta}_{l} \sum_{i \in j} l_{i}-\hat{\beta}_{k} \sum_{i \in j} k_{i}$

The productivity of firms relative to their industry is given by:

$$
R T F P_{i}=\ln T F P_{i}-\ln T F P_{j}
$$

16 In order to use the average value of TFP in industry level estimations, we excluded industry dummies from the estimation to maintain the differences of TFP among industries. 


\section{References}

Abe, Takeshi, Kazuya Hitomi, Yoko Konishi, Hideaki Tomita and Taisuke Uchino (2012) “A New Converter for Establishments from Japan's Census of Manufactures: 19932009," Policy Discussion Paper, 12-P-007, RIETI.

Aghion, P., Blundell, R., Griffith, R., Howitt, P. and S. Prantl (2004), "Entry and Productivity Growth: Evidence from Microlevel Panel Data,” Journal of European Economic Association, 2(2-3)_: 265-276.

Alessandra, G. and H. Choi (2007). “Do Sunk Costs of Exporting Matter for Export Dynamics,” Quarterly Journal of Economics, 122(1).

Axarloglou, Kostas, (2003) “The Cyclicality of New Product Introductions” Journal of Business 76, 29-48.

Berman, Nicholas, Philippe Martin, and Thierry Mayer (2011) “How Do Different Exporters React to Exchange Rate Changes?” Quarterly Journal of Economics 127, pp. 437-492.

Bernard, Andrew, B. and Toshihiro Okubo (2013), "Multi-Product Plants and Product Switching in Japan” RIETI Discussion Paper Series, 13-E-069.

Bernard, Andrew, B. and Toshihiro Okubo (2015), "Product Switching and the Business Cycle,” RIETI Discussion Paper Series, 15-E-103.

Bergin, P. and G. Corsetti (2014), "International Competitiveness and Monetary Policy," manuscript, Cambridge University.

Bernard, Andrew, B., Stephen J. Redding, and Peter K. Schott (2010) “Multi-Product Firms and Product Switching,” The American Economic Review, 100, pp. 70-97

Bilbie, F., Ghironi, F., and M. Melitz (2012), “Endogenous Entry, Product Variety, and Business Cycles,” Journal of Political Economy, 120(2): 304-345.

Broda, C. and D. Weinstein (2010). "Product Creation and Destruction: Evidence and Price Implications,” American Economic Review, 100(3), p. 691-723. 
Chatterjee, Arpita, Rafael Dix-Carneiro, and Jade Vichyanond (2013) “Multi-Product Firms and Exchange Rate Fluctuations” American Economic Journal: Economic Policy 5, pp. 77-110.

Corsetti, Giancarlo, Philippe Martin, and Paolo Pesenti (2007) "Productivity. Terms of Trade and ‘Home Market Effect’” Journal of International Economics 73, pp. 99-127.

Davis, Steven, John Haltiwanger, and Scott Schuh (1996), Job Creation and Destruction, Cambridge, M.A.: MIT Press.

Dekle, Robert, Hyeok Jeong, and Nobuhiro Kiyotaki (2014) "Dynamics of Firms and Trade in General Equilibrium” unpublished manuscript March, 2014.

di Giovanni, Julian, Andrei A. Levchenko, and Isabelle Méjean (2014) “Firms, Destinations, and Aggregate Fluctuations,” Econometrica 82, pp. 1303-1340

Foster, Lucia, John Haltiwanger, and Chad Syverson (2008), “Reallocation, Firm Turnover, and Efficiency: Selection on Productivity or Profitability?” The American Economic Review 2008 98, pp.394-425.

Fukao, Kyoji, and Hyeog Ug Kwon (2006), “Why Did Japan’s TFP Growth Slow Down in the Lost Decade? An Empirical Analysis Based on Firm-Level Data of Manufacturing Firms” The Japanese Economic Review 57, pp. 195-228.

Ghironi, Fabio and Marc J. Melitz (2005), “International Trade and Macroeconomic Dynamics with Heterogeneous Firms” Quarterly Journal of Economics 121, pp. 865-915.

Goldberg, Pinelopi Koujianou, and Michael Knetter (1997) “Goods Prices and Exchange Rates: What Have We Learned?” Journal of Economic Literature 35, pp. 1243-1272.

Kawakami, Atsushi, Tsutomu Miyagawa, and Miho Takziawa (2011) “Revisiting Productivity Differences and Firm Turnover -Evidence for Product-Based TFP Measure in the Japanese Manufacturing Industries” RIETI Discussion Paper Series 11-E-064.

Kawakami, Atsushi, and Tsutomu Miyagawa (2013) "Product Switching and Firm Performance in 
Japan” Public Policy Review 9, pp. 287-314, Policy Research Institute, Ministry of Finance.

Krugman, Paul (1987) “Pricing to Market When the Exchange Rate Changes”, S. Arndt and J.

Richardson eds., Real-Financial Linkages among Open Economies, The MIT Press, Cambridge, MA.

Meese, R. and K.Rogoff (1983), “Empirical Exchange Rate Models of the Seventies: Do They Fit Out of Sample,” Journal of International Economics, 14: 3-24.

Moreira, S. (2016). “Firm Dynamics, Persistent Effects of Entry Conditions and Business Cycles,” manuscript, University of Chicago.

Olley, G. Steven and Pakes, Ariel (1996) "The Dynamics of Productivity in the Telecommunications Equipment Industry”, Econometrica, 64, pp. 1263-1293.

Melitz, Marc, J., (2003) “The Impact of Trade on Intra-Industry Reallocations and Aggregate Industry Productivity” Econometrica 71, pp. 1695-1725.

Nakamura, Emi and J. Steinnson (2012). “Lost in Transit: Product Replacement Bias and Pricing to Market,” American Economic Review, 102, 3277-3316.

Sato Kiyotaka, Junko Shimizu, Nagendra Shrestha, and Shajuan Zhang (2012) “The Construction and Analysis of Industry-specific Effective Exchange Rates in Japan” RIETI Discussion Paper Series 12-E-043.

Shioji Etsuro (2012) “The Evolution of Exchange Rate Pass-Through in Japan: A Re-evaluation Based on Time-Varying Parameter VARs” Public Research Policy 8, 67-92, Policy Research Institute, Ministry of Finance.

Syverson, Chad (2011) “What Determines Productivity?” Journal of Economic Literature 49, pp. 326-365.

Yasar, Mahmut, Raciborski, Rafal and Poi, Brian (2008) "Production Function Estimation in Stata Using the Olley and Pakes Method”, The Stata Journal, 8, pp. 221-231. 
Table 1

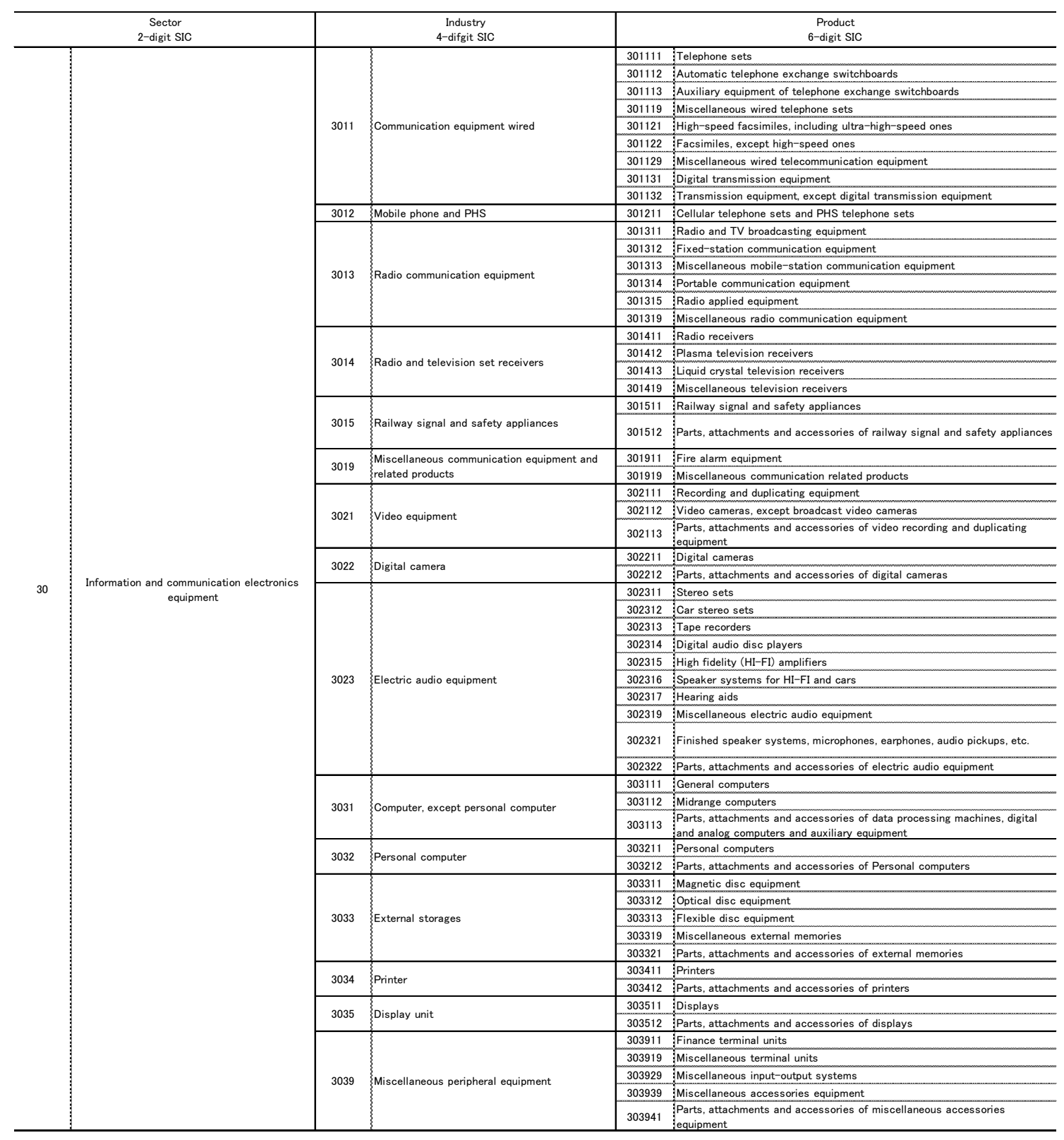


Table 2

\begin{tabular}{|c|c|c|c|c|c|c|}
\hline Sector & Industries & Products & $\begin{array}{l}\text { Industries/ } \\
\text { Products }\end{array}$ & $\begin{array}{c}\text { Goods } \\
\text { Shipments } \\
\text { (million yen) }\end{array}$ & $\begin{array}{l}\text { Number of } \\
\text { Empliyees }\end{array}$ & $\begin{array}{l}\text { Shipments } \\
\text { per } \\
\text { Employees } \\
\text { (million yen) }\end{array}$ \\
\hline $9 \mathrm{FOOD}$ & 41 & 87 & 2.1 & 23784327 & 1049968 & 22.7 \\
\hline 10 BEVERAGES,TOBACCO AND FEED & 13 & 31 & 2.4 & 9802268 & 91072 & 107.6 \\
\hline 11 TEXTILE MILL PRODUCTS & 64 & 177 & 2.8 & 3493573 & 257219 & 13.6 \\
\hline 12 LUMBER AND WOOD PRODUCTS, EXCEPT FOURNITURE & 18 & 43 & 2.4 & 1824205 & 75766 & 24.1 \\
\hline 13 FURNITURE AND FIXTURES & 9 & 22 & 2.4 & 1402558 & 77669 & 18.1 \\
\hline 14 PULP, PAPER AND PAPER PRODUCTS & 15 & 52 & 3.5 & 6895796 & 177263 & 38.9 \\
\hline 15 PRINTING AND ALLEDD INDUSTRIES & 7 & 19 & 2.7 & 5724091 & 262370 & 21.8 \\
\hline 16 CHEMICAL AND ALUED PRODUCTS & 38 & 160 & 4.2 & 24096231 & 340916 & 70.7 \\
\hline 17 PETROLEUM AND COAL PRODUCTS & 5 & 18 & 3.6 & 10241165 & 21956 & 466.4 \\
\hline 18 PLASTIC PRODUCTS, EXCEPT OTHERWISE CLASSIFIED & 25 & 54 & 2.2 & 9669225 & 383831 & 25.2 \\
\hline 19 RUBBER PRODUCTS & 13 & 40 & 3.1 & 2577212 & 108561 & 23.7 \\
\hline 20 LEATHER TANNING, LEATHER PRODUCTS AND FUR SKINS & 9 & 30 & 3.3 & 328166 & 20288 & 16.2 \\
\hline 21 CERAMIC, STONE AND CLAY PRODUCTS & 44 & 101 & 2.3 & 6186607 & 223326 & 27.7 \\
\hline 22 IRON AND STEEL & 22 & 65 & 3.0 & 15751510 & 210931 & 74.7 \\
\hline 23 NON-FERROUS METALS AND PRODUCTS & 17 & 55 & 3.2 & 6847263 & 136256 & 50.3 \\
\hline 24 FABRICATED METAL PRODUCTS & 33 & 127 & 3.8 & 11383456 & 488184 & 23.3 \\
\hline 25 GENERAL-PURPOSE MACHINERY & 19 & 97 & 5.1 & 9604354 & 301692 & 31.8 \\
\hline 26 PRODUCTION MACHINERY & 26 & 127 & 4.9 & 11389401 & 474074 & 24.0 \\
\hline 27 BUSINESS ORIENTED MACHINERY & 23 & 84 & 3.7 & 6951459 & 206822 & 33.6 \\
\hline 28 ELECTRONIC PARTS, DEVICES AND ELECTRONIC CIRCUITS & 15 & 68 & 4.5 & 14819858 & 453435 & 32.7 \\
\hline 29 ELECTRICAL MACHINERY, EQUIPMENT AND SUPPLES & 23 & 111 & 4.8 & 13485422 & 453686 & 29.7 \\
\hline 30 INFORMATION AND COMMUNICAION ELECTRONICS EQUIPMET & 15 & 55 & 3.7 & 11427859 & 214300 & 53.3 \\
\hline 31 TRANSPORTATION EQUIPMENT & 16 & 66 & 4.1 & 46946916 & 923495 & 50.8 \\
\hline 32 MISCELLANEOUS MANUFACTURING INDUSTRIES & 32 & 114 & 3.6 & 3521578 & 132655 & 26.5 \\
\hline
\end{tabular}

Note) We calculate these values of report by industry of the 2009 census. 
Table 3-1

Dependent Variable: $\Delta$ Number of Products

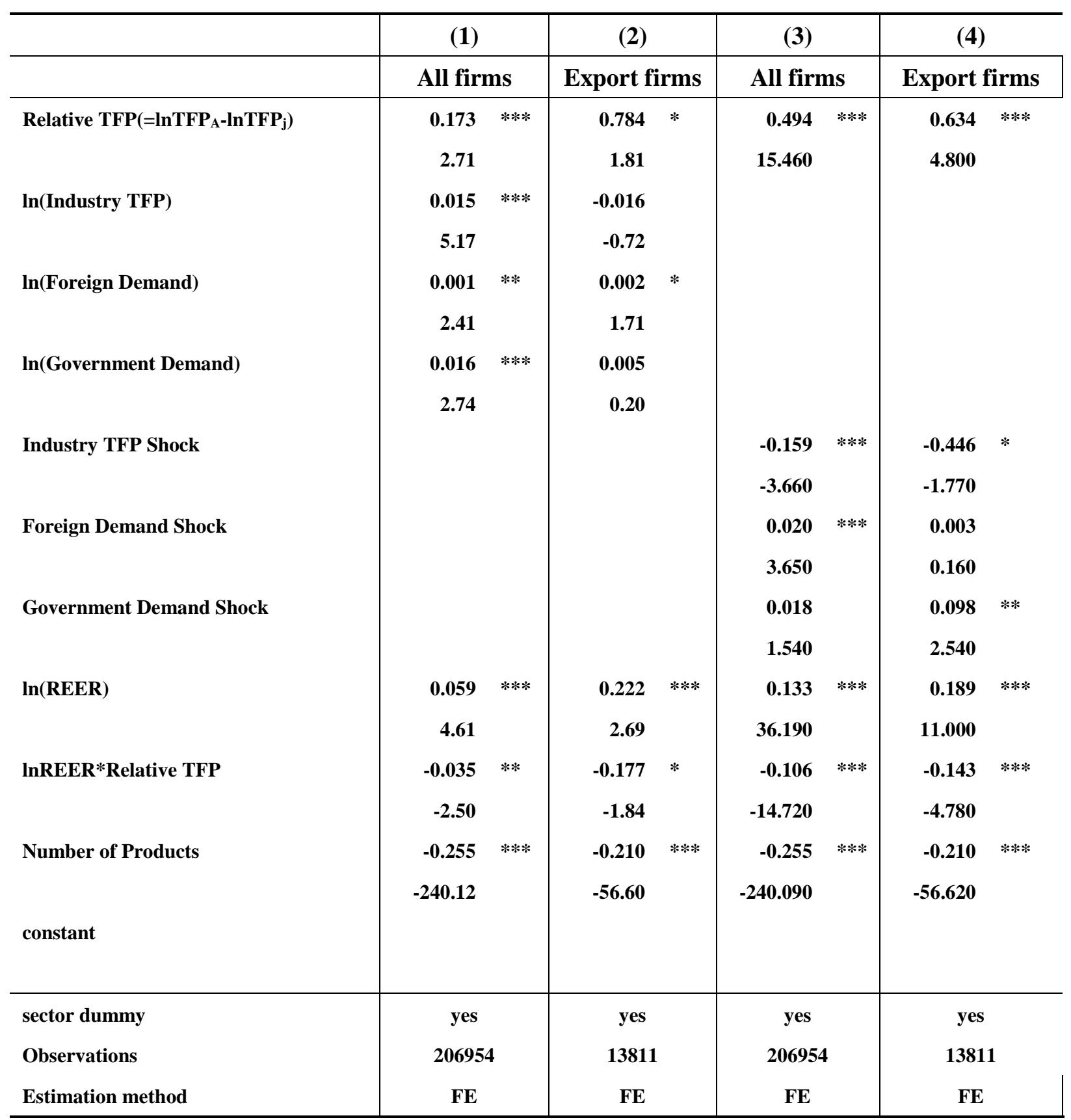


Table 3-2

Dependent Variable: Rate of Change in the Number of Products:

(Change in Number of Products/Total Number of Products)

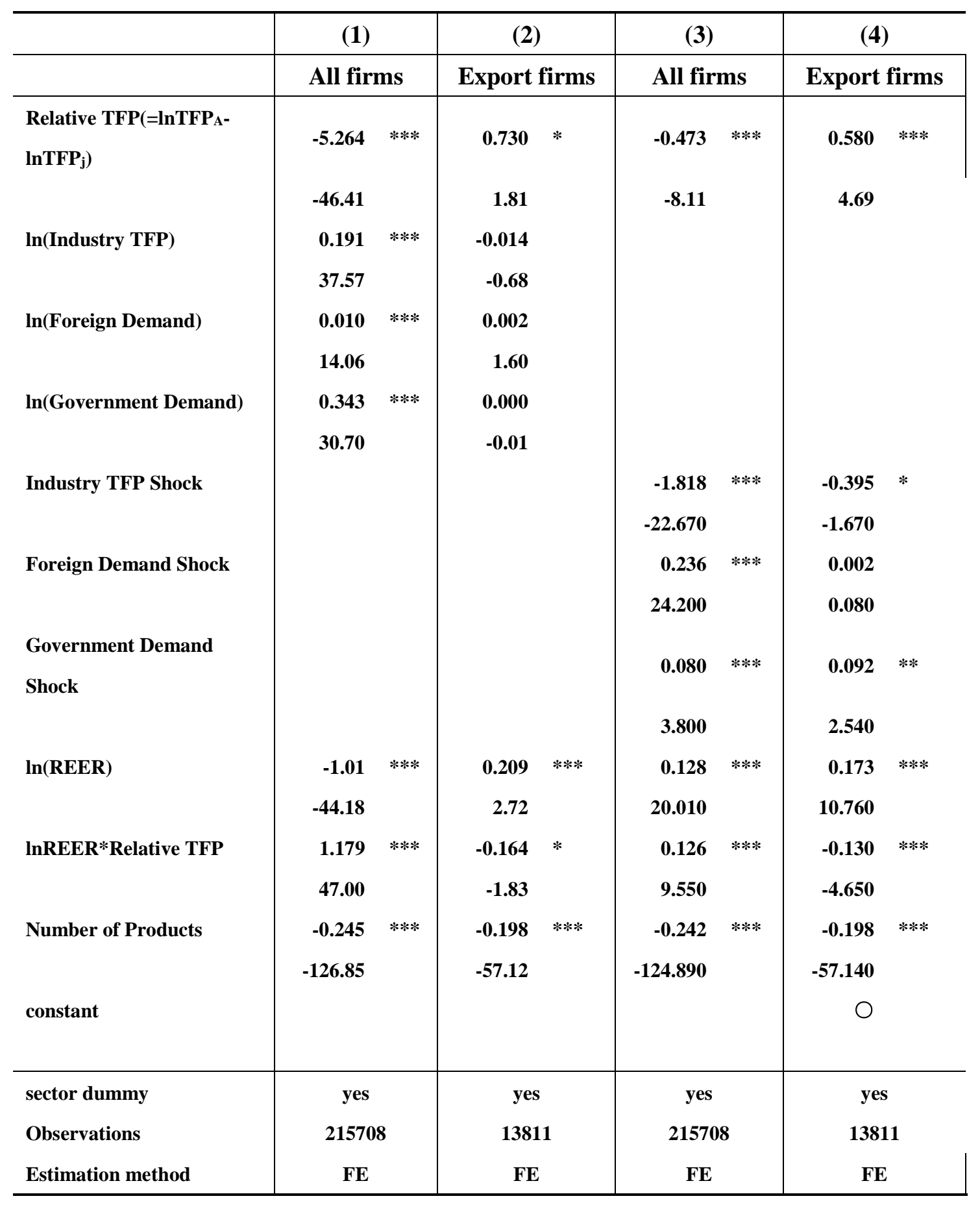




\section{Table 4-1}

Dependent Variable: Adding Dummy Variable (Logit Panel

Estimation)

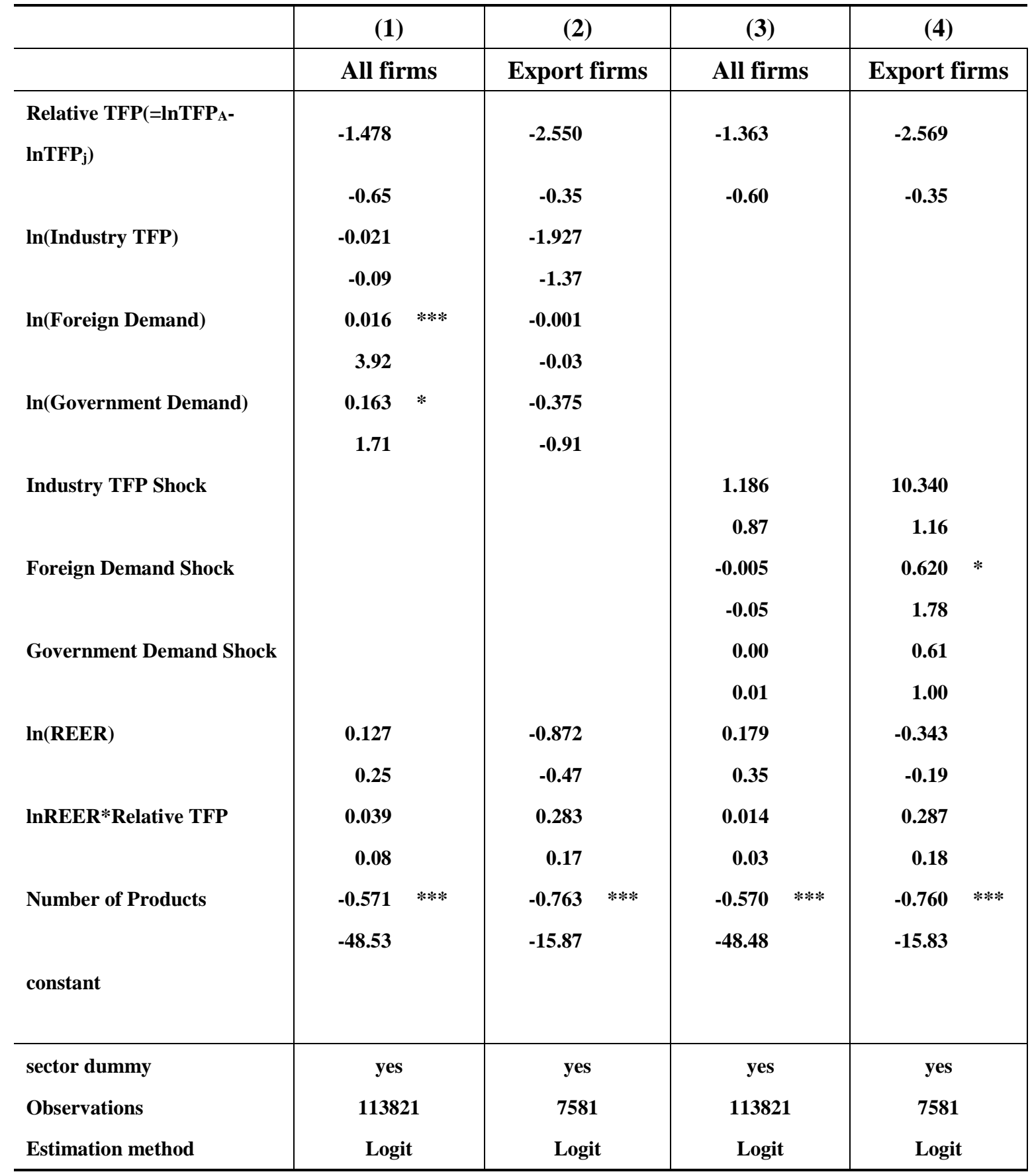


Table 4-2

Dependent Variable: Rate of Product Adding

(Number of Products Added/Total Number

of Products)

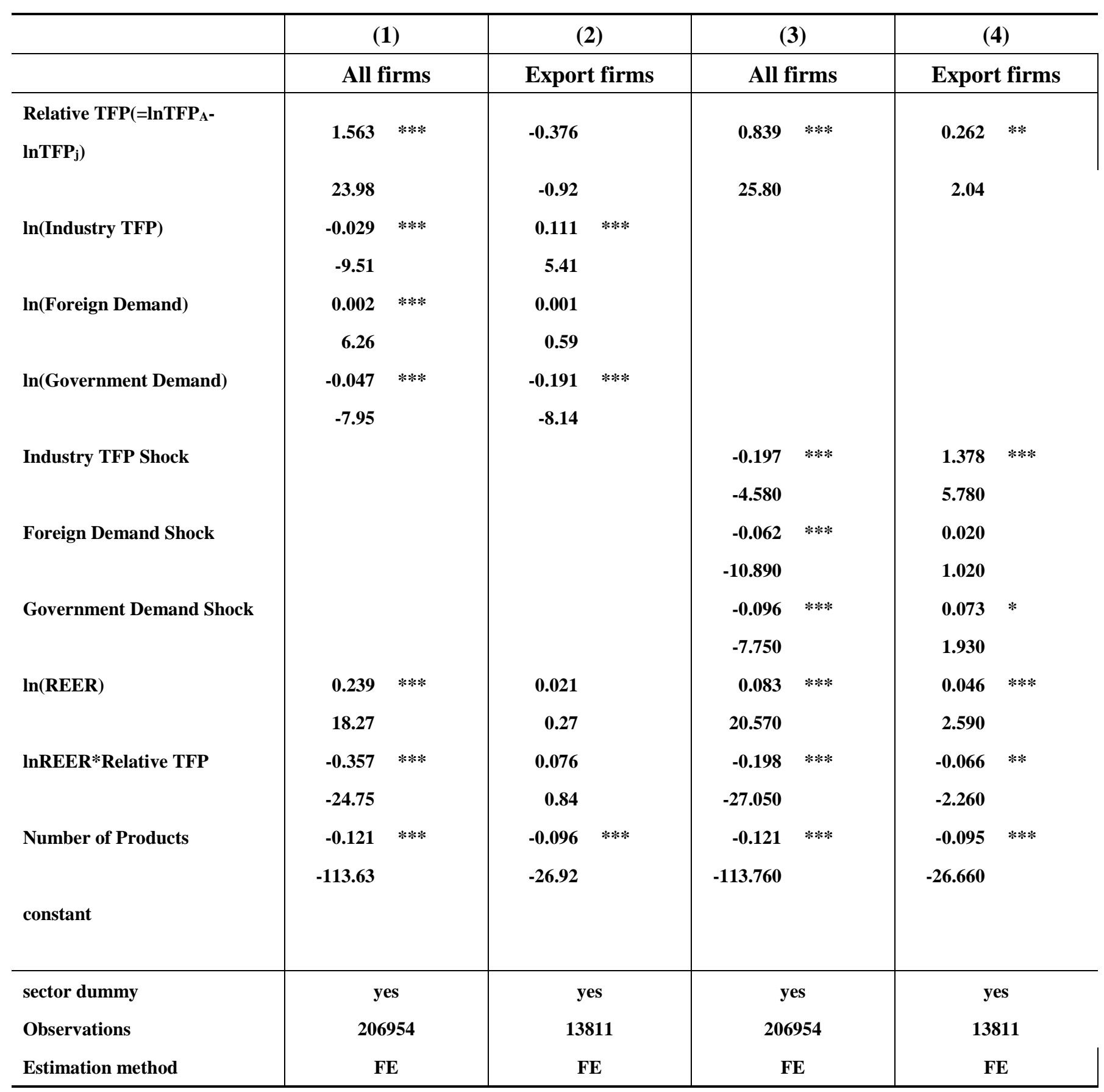




\section{Table 5-1}

Dependent Variable: Dropping Dummy Variable (Panel Logit Estimation)

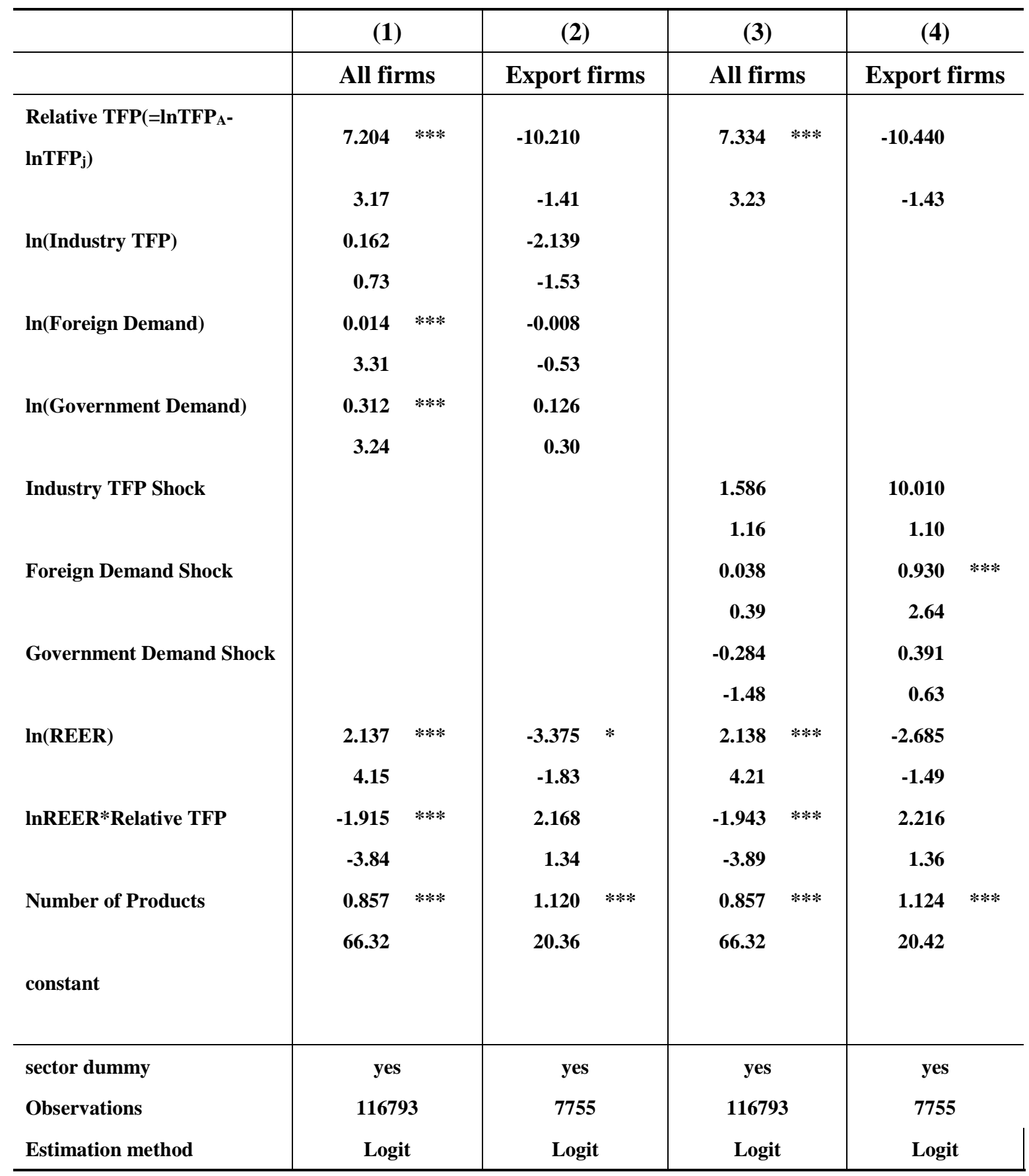


Table 5-2

Dependent Variable: Rate of Product

Dropping (Number of Products

Dropped/Total Number of Products)

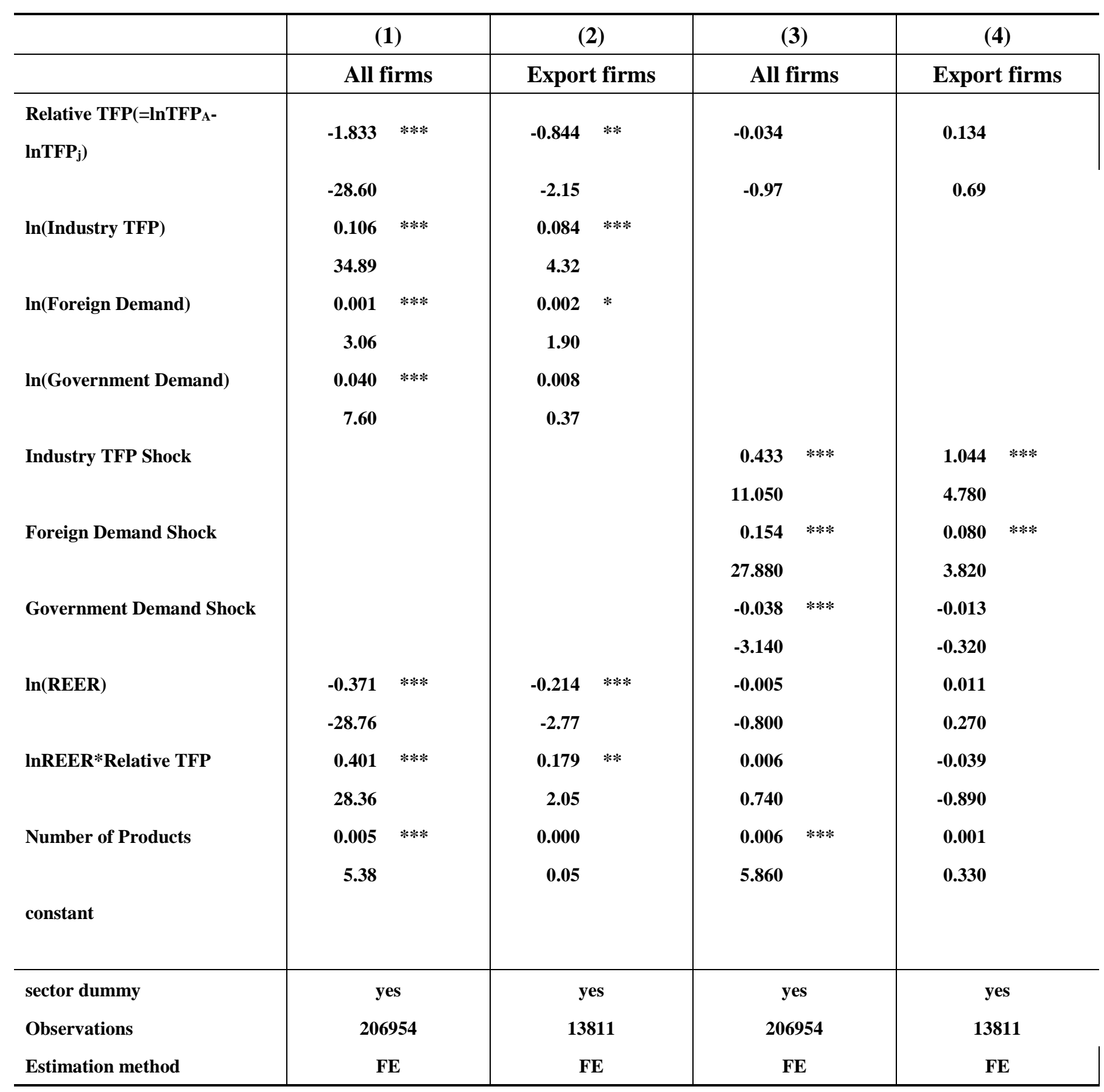


Table 6

Dependent Variable: Adding and Dropping Dummy Variable (Panel Logit Estimation)

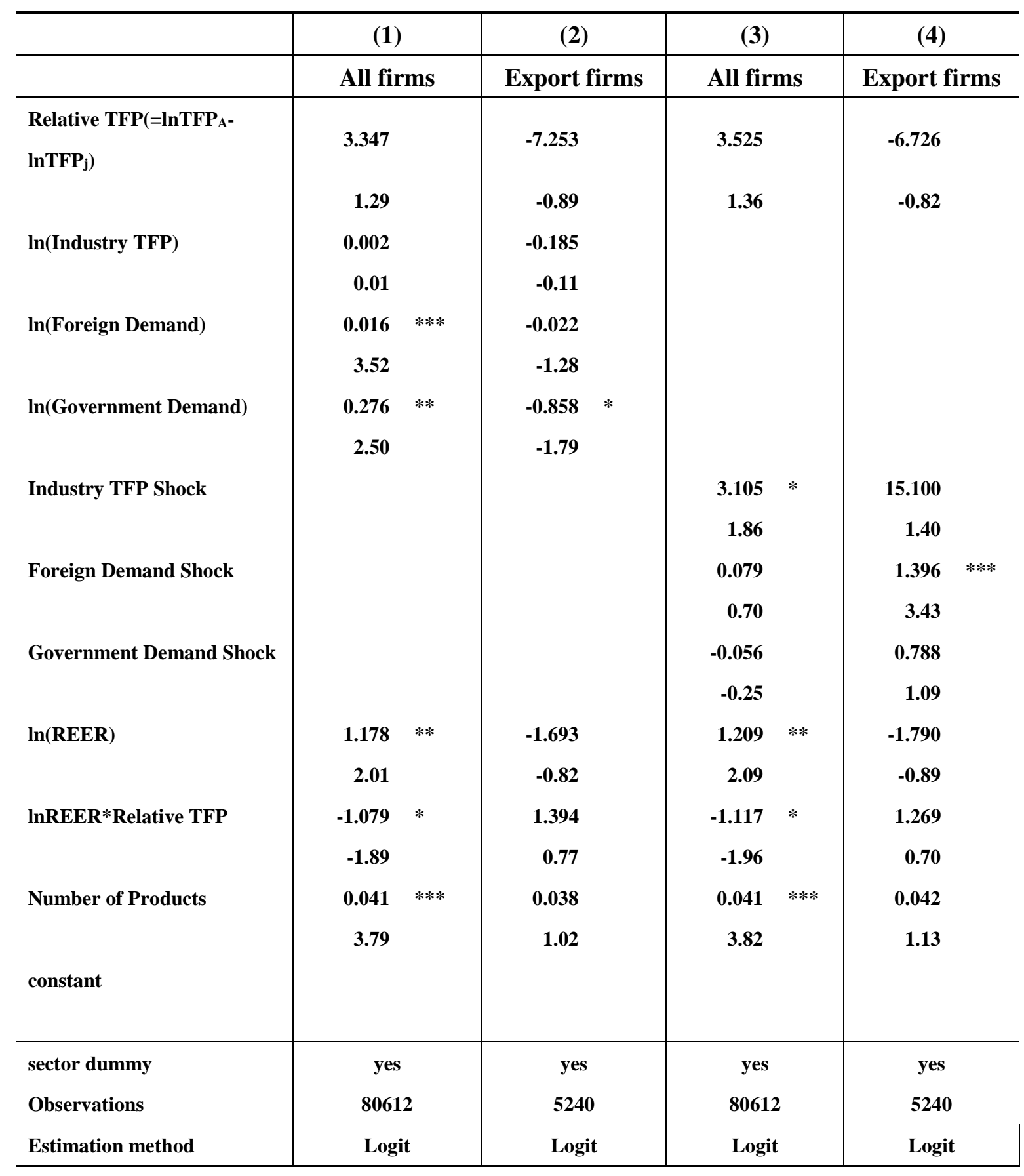




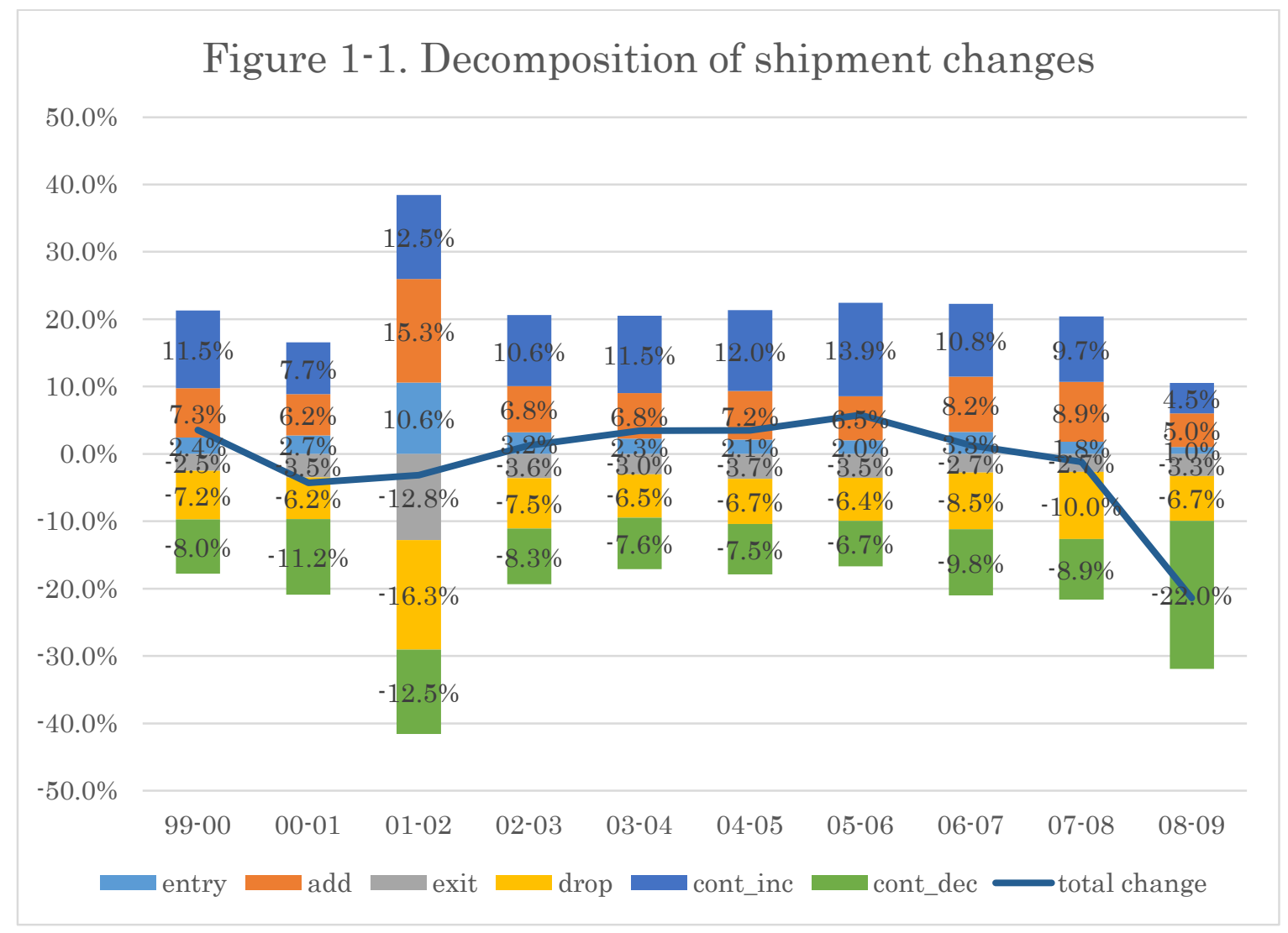




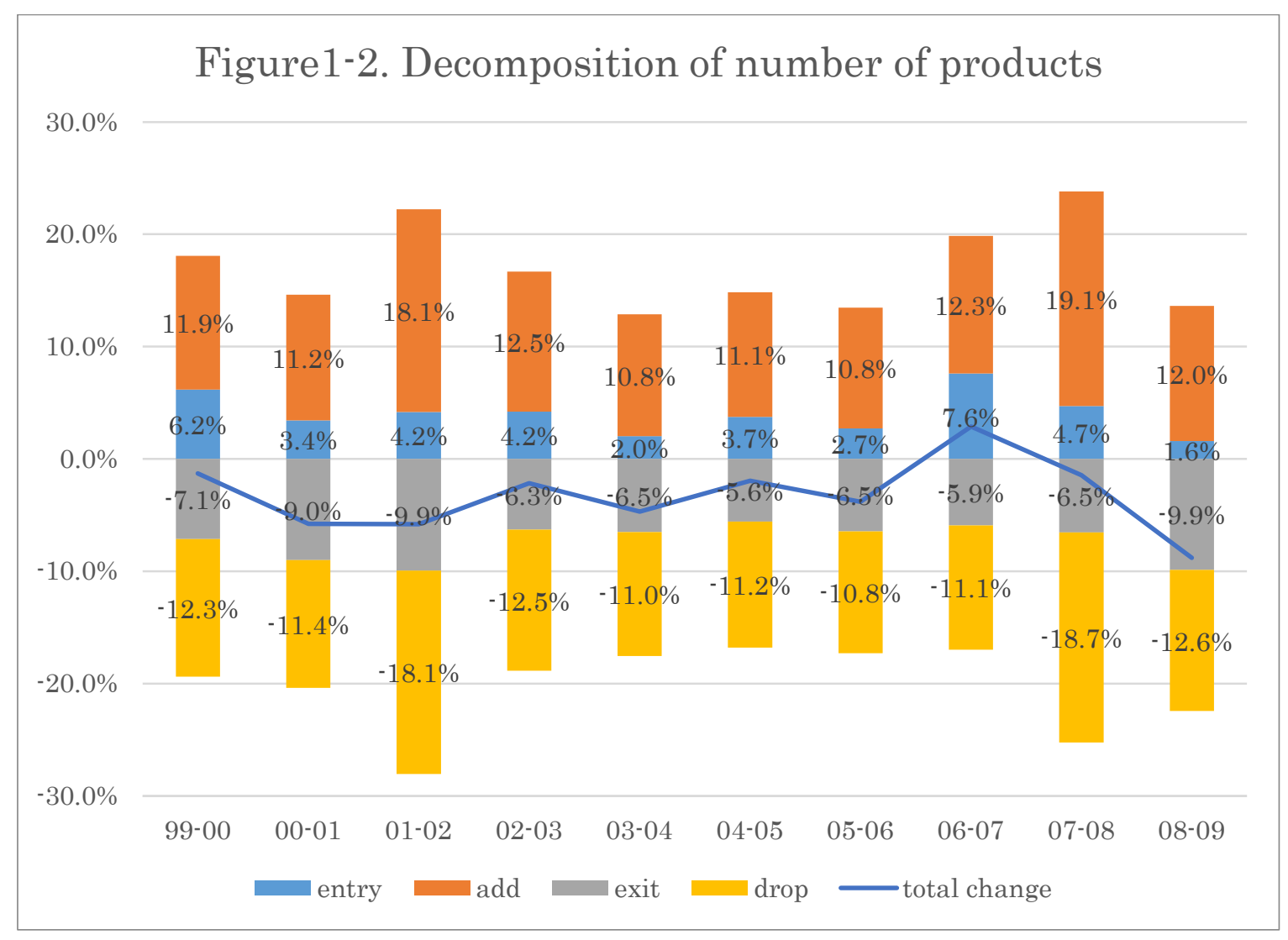


Figure2-1. Decomposition of shipment change (high productivity firms)

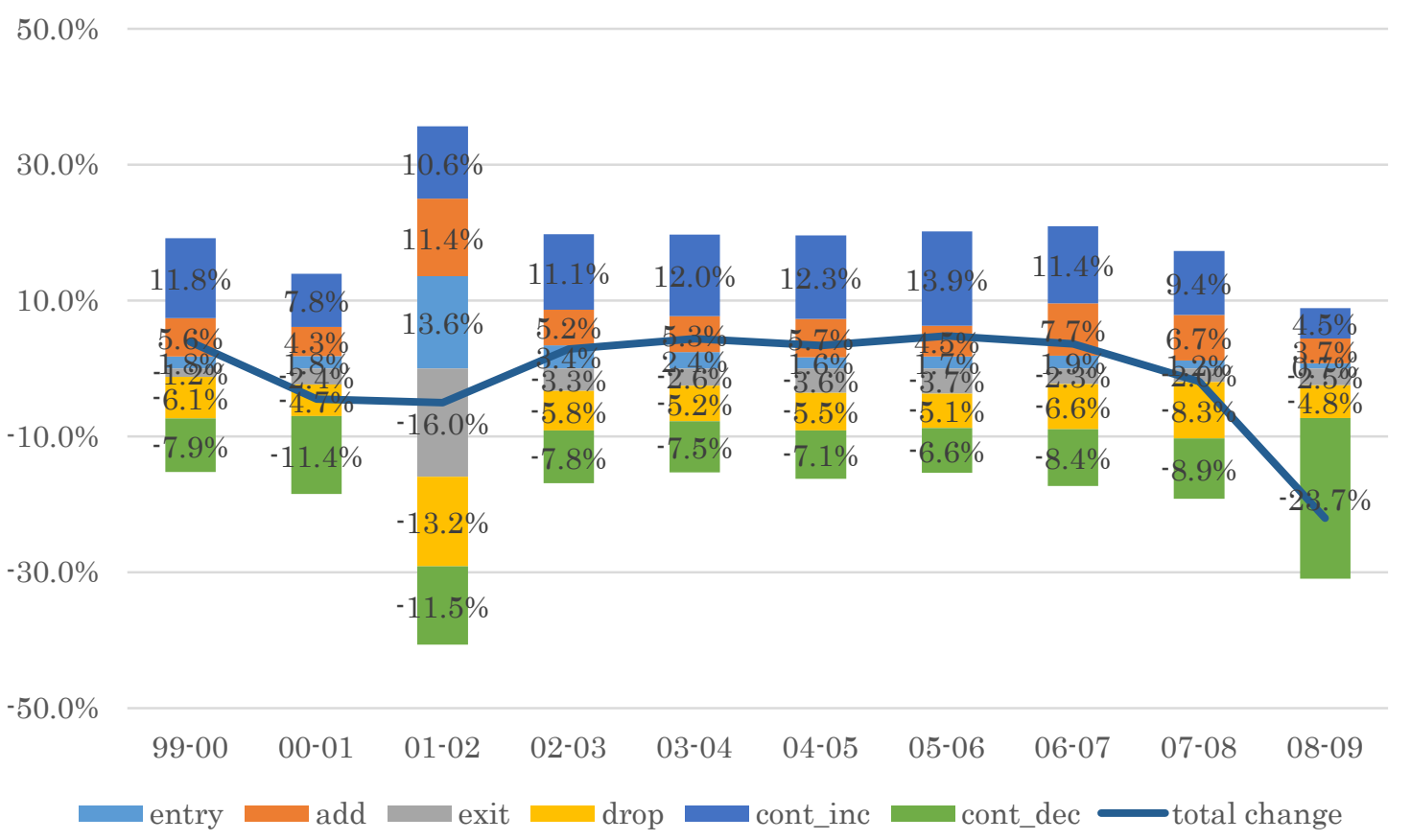


Figure 2-2. Decomposition of shipment change (low productivity firms)

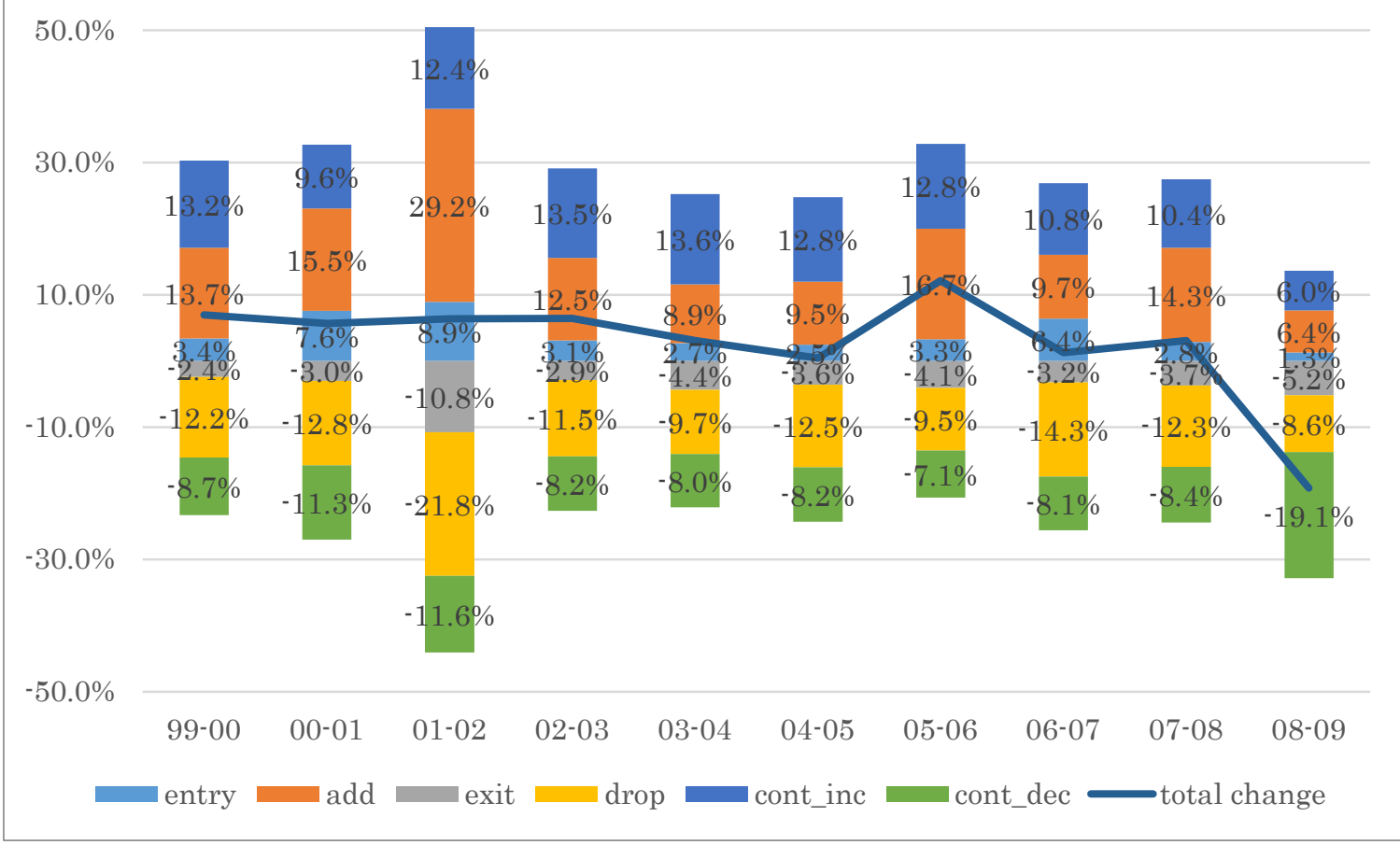




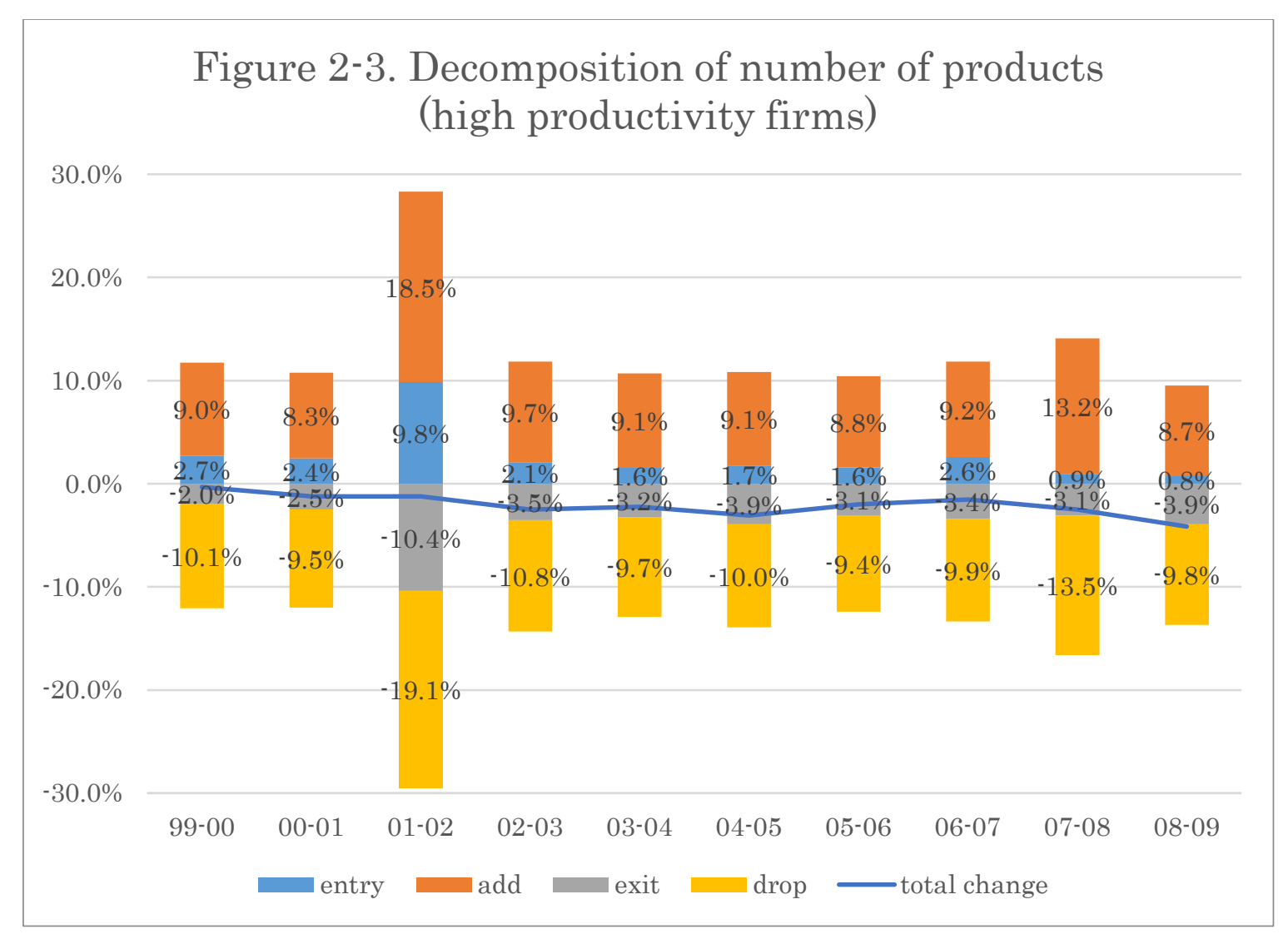




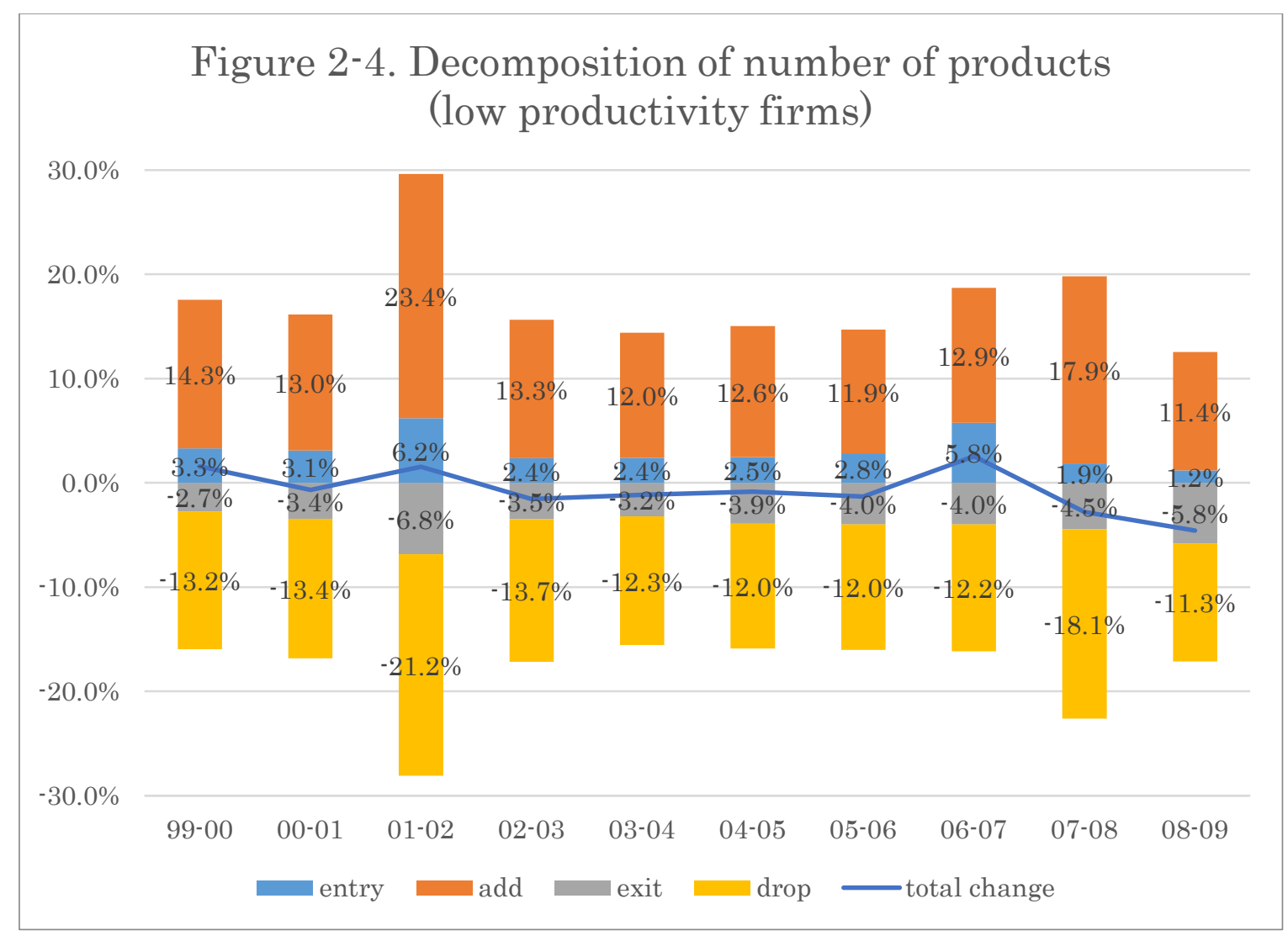




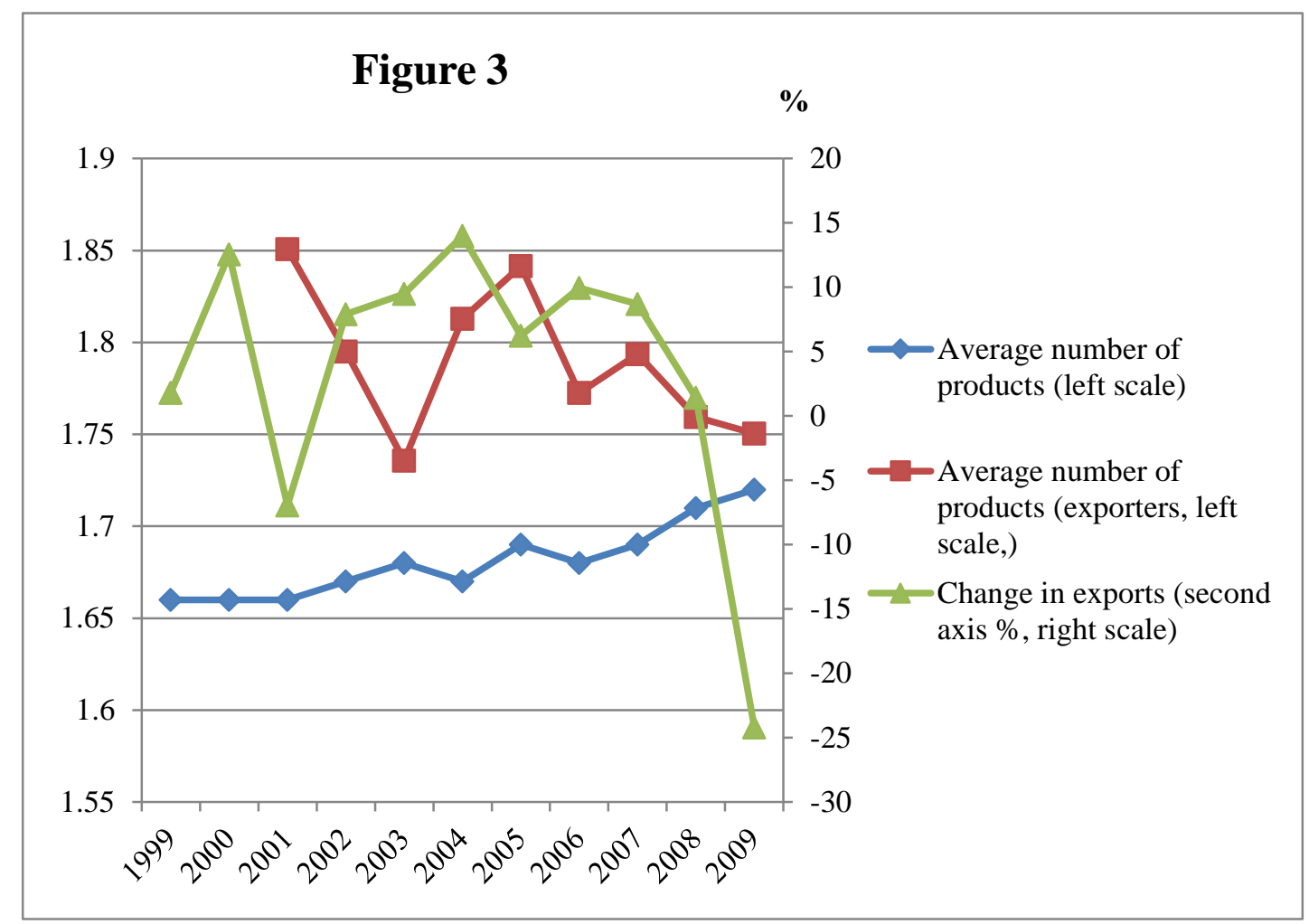


Figure 4

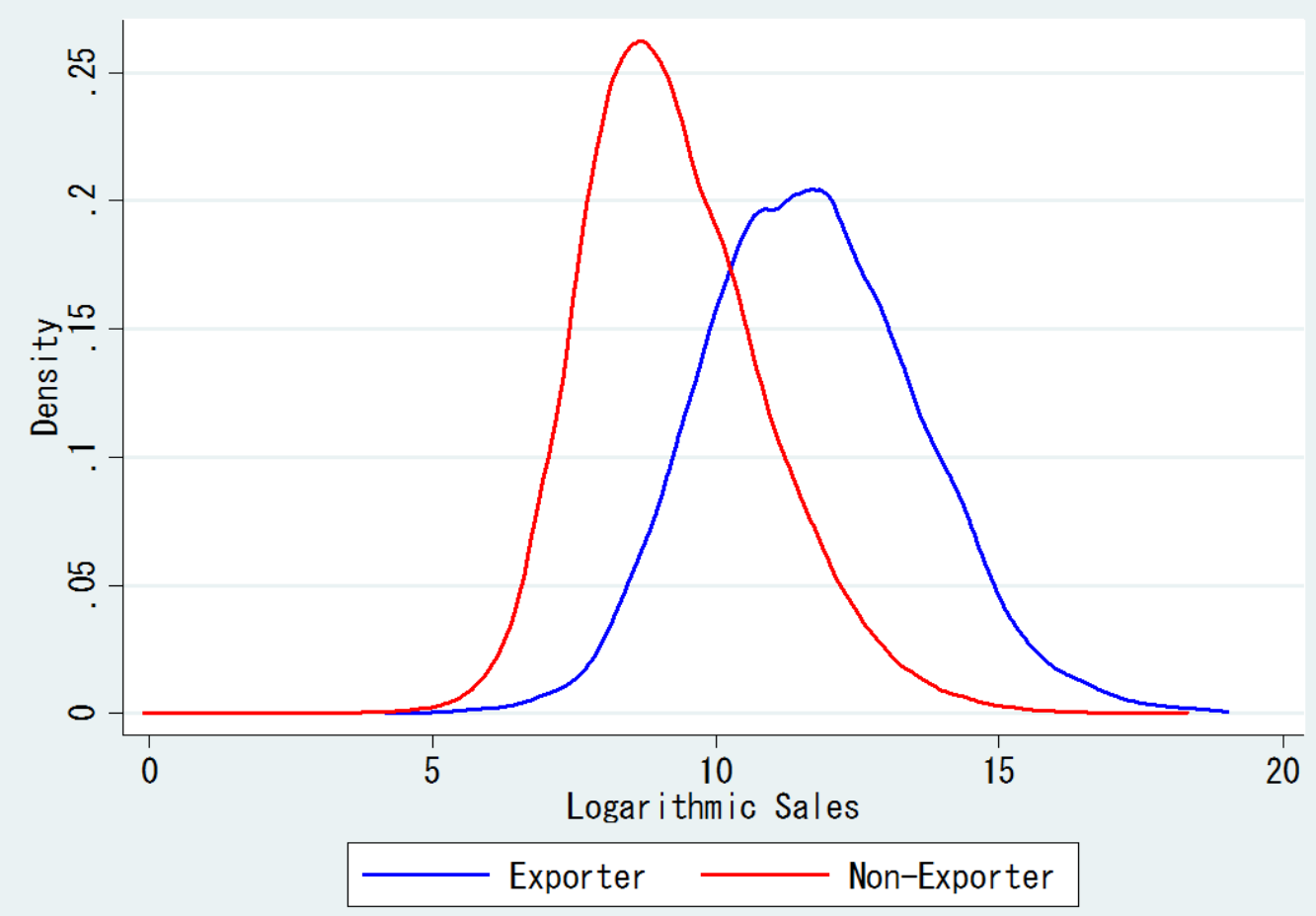


Figure 5 Number of added and dropped products

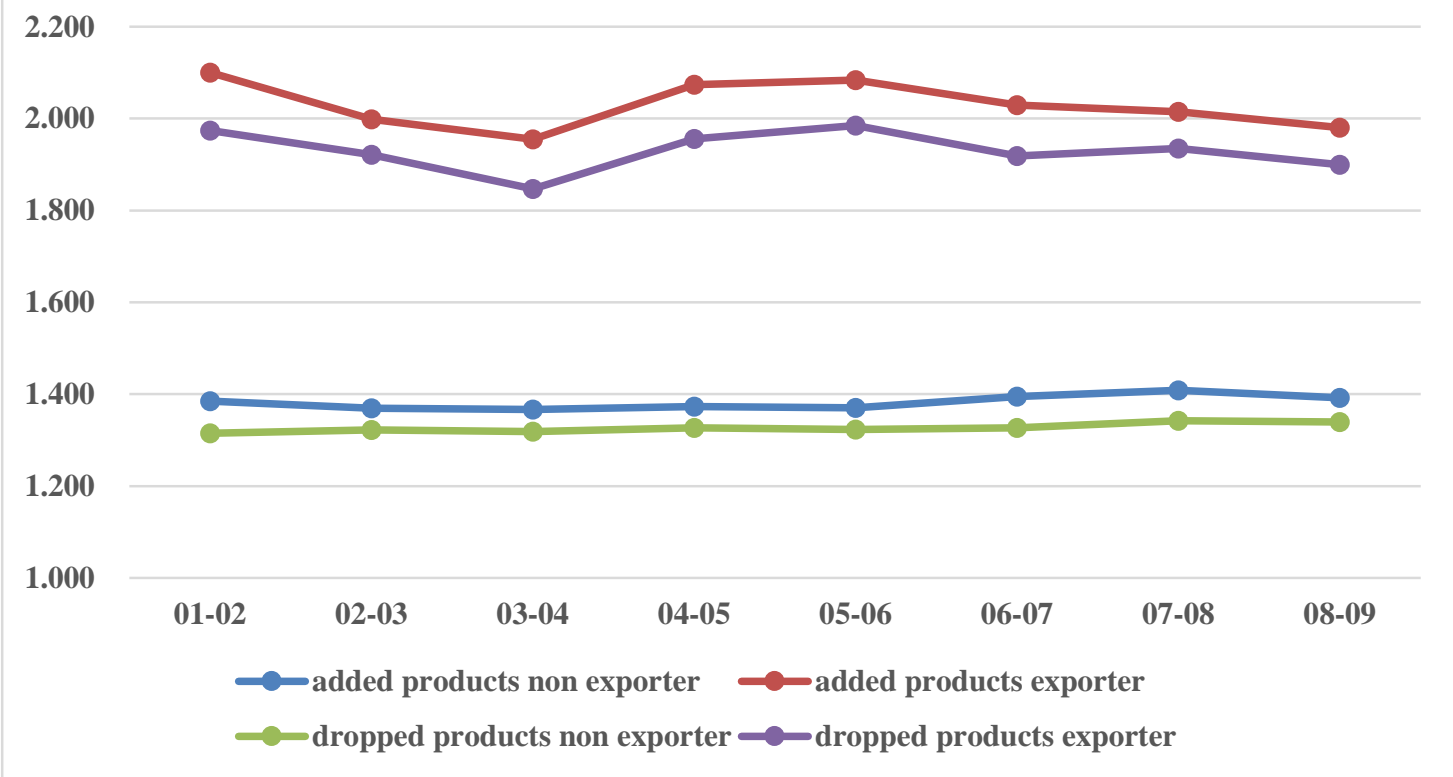




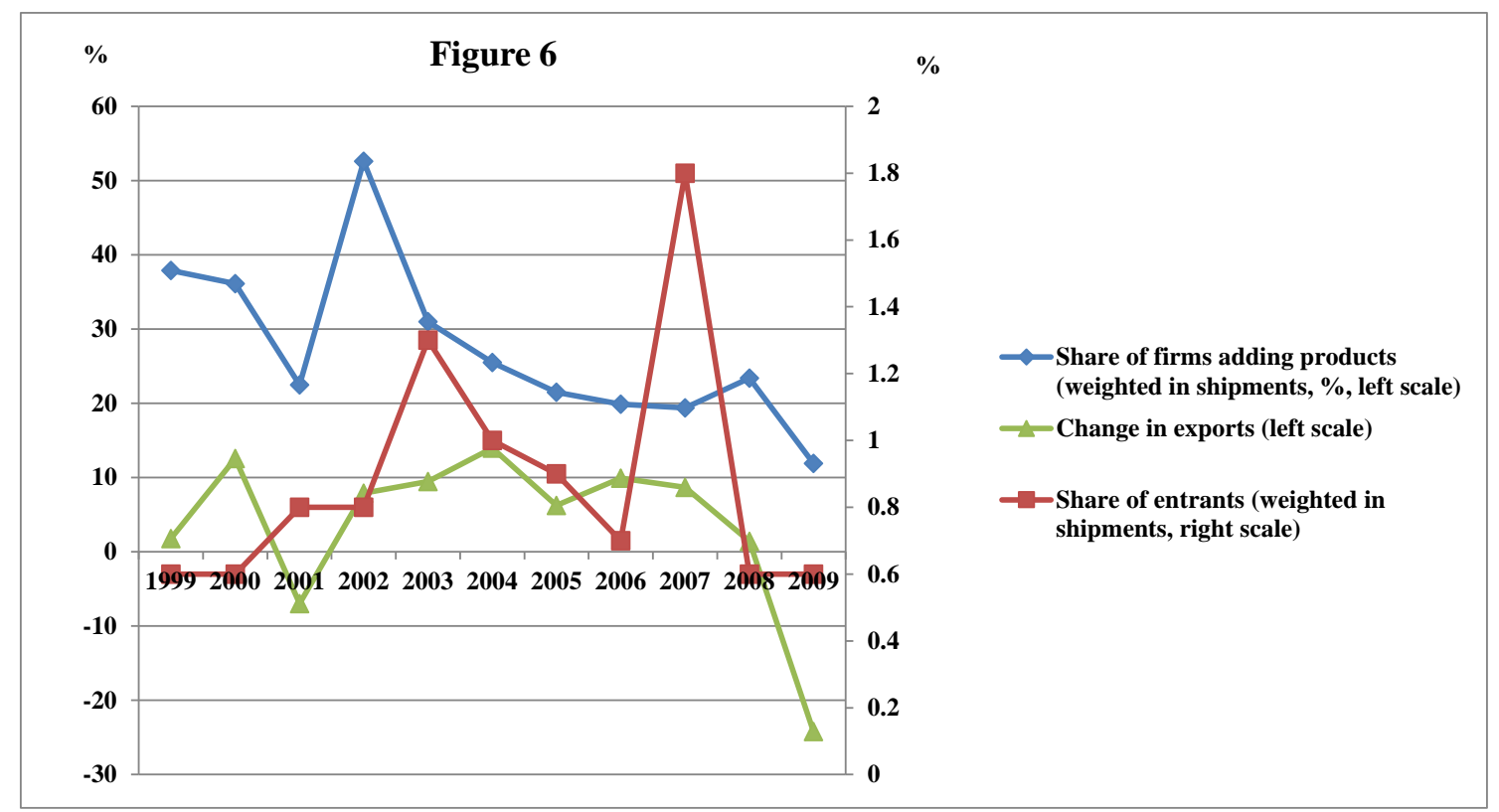




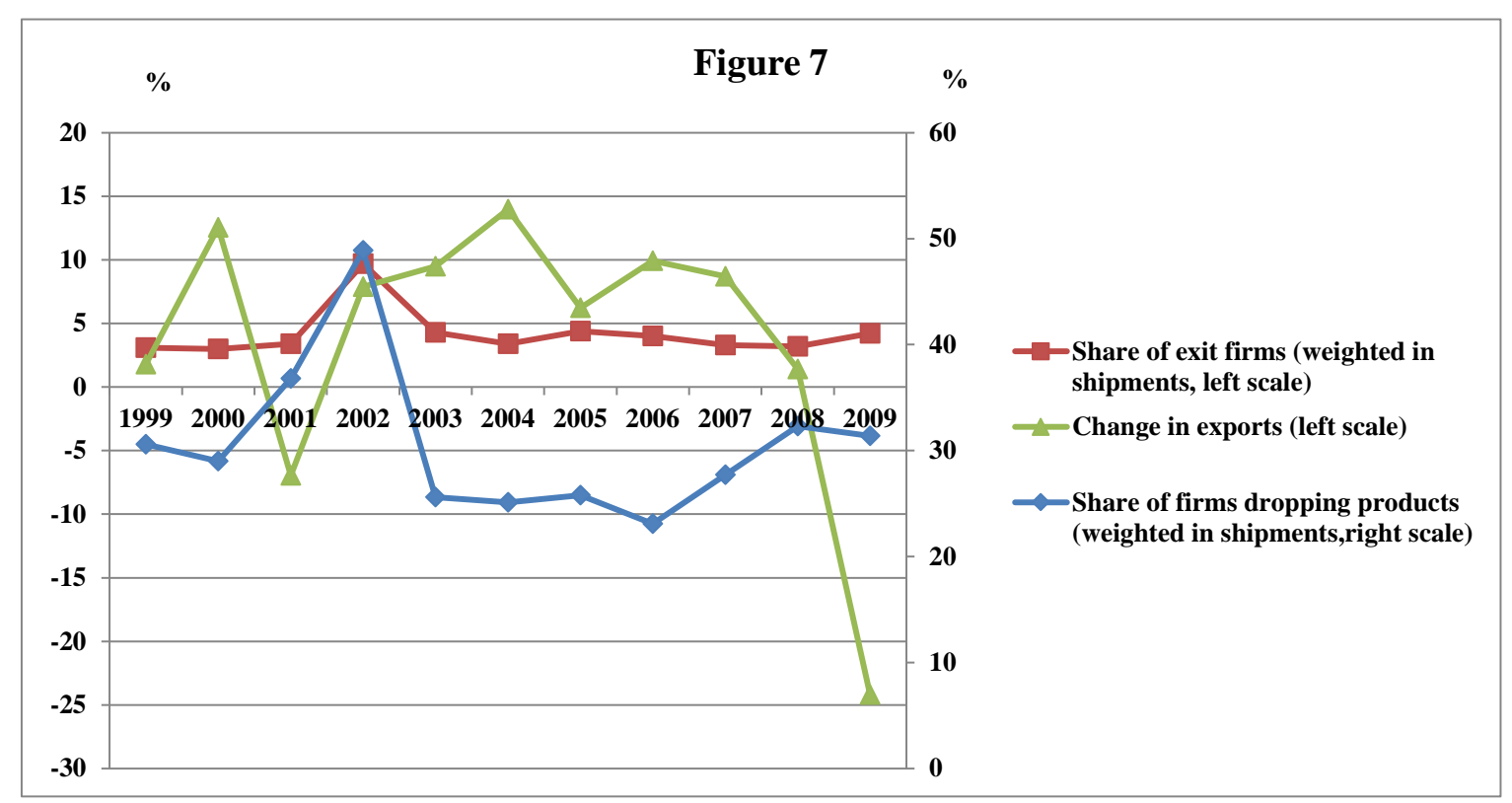

